\title{
Mobility patterns in inland southwestern Sweden during the Neolithic and Early Bronze Age
}

\author{
Malou Blank ${ }^{1}$ (D) $\cdot$ Karl-Göran Sjögren ${ }^{1} \cdot$ Corina Knipper $^{2} \cdot$ Karin M Frei $^{3} \cdot$ Helena Malmström $^{4,5} \cdot$ Magdalena Fraser $^{4}$. \\ Emma M. Svensson ${ }^{4} \cdot$ Torsten Günther $^{4}$ • Hannes Yngve ${ }^{4}$ - Mattias Jakobsson ${ }^{4,5}$ • Anders Götherström ${ }^{6}$ • Jan Storå ${ }^{7}$
}

Received: 6 August 2020 / Accepted: 1 February 2021 / Published online: 18 March 2021

(C) The Author(s) 2021

\begin{abstract}
In this paper, we investigate population dynamics in the Scandinavian Neolithic and Early Bronze Age in southwestern Sweden. Human mobility patterns in Falbygden were studied by applying strontium isotope analysis combined with archaeological and bioarchaeological data, including mtDNA and sex assessment on a large dataset encompassing 141 individuals from 21 megalithic graves. In combination with other archaeological and anthropological records, we investigated the temporal and spatial scale of individual movement, mobility patterns of specific categories of people and possible social drivers behind them. Our results of strontium and biomolecular analyses suggest that mobility increased in the Late Neolithic and Early Bronze Age compared to the earlier parts of the Neolithic. The data indicate individuals moving both into and away from Falbygden. Mobility patterns and contact networks also shift over time.
\end{abstract}

Keywords Mobility $\cdot$ Southwestern Sweden $\cdot$ Megalithic graves $\cdot$ Strontium isotopes $\cdot$ Mitochondrial aDNA $\cdot$ Neolithic $\cdot$ Early Bronze Age

\section{Introduction}

The Scandinavian Neolithic (4000-1700 cal BC) and Early Bronze Age (1700-1100 cal BC) were times of important cultural transformations and human migrations. Some of the

Malou Blank

malou.blank.backlund@gu.se

1 Department of historical studies, University of Gothenburg, Gothenburg, Sweden

2 Curt-Engelhorn Center for Archaeometry, Mannheim, Germany

3 National Museum of Denmark, Environmental Archaeology and Materials Science, Kongens Lyngby, Denmark

4 Human Evolution, Department of Organismal Biology, Uppsala University, Uppsala, Sweden

5 Centre for Anthropological Research, University of Johannesburg, Johannesburg, South Africa

6 Centre for Palaeogenetics, Department of Archaeology and Classical Studies, Stockholm University, Stockholm, Sweden

7 Osteoarchaeological Research Laboratory, Department of Archaeology and Classical Studies, Stockholm University, Stockholm, Sweden drivers behind these changes were agriculture introduced by Funnelbeaker/Trichterbecher Culture (TRB) groups ca $4000 \mathrm{cal} \mathrm{BC}$ and growing long-distance exchange networks and imports of metal objects in the Late Neolithic (2200 $1700 \mathrm{cal}$ BC). In inland southwestern Sweden, regional networks and contacts within southern Scandinavia, and indirectly with continental Europe, can be attested by building traditions, burial practices and imported goods (Apel 2001; Sjögren 2003; Weiler 1994).

According to recent results from ancient DNA (aDNA) research, migration was an important factor for the spread of the TRB complex and agriculture into Scandinavia (e.g. Linderholm 2008; Malmström et al. 2015; Mittnik et al. 2018; Skoglund et al. 2012, 2014). Furthermore, results from several aDNA studies (Allentoft et al. 2015; Haak et al. 2015) demonstrate that populations from the Pontic-Caspian steppe expanded and settled in Europe from around $2800 \mathrm{cal} \mathrm{BC}$. A recent study has confirmed that Nordic Corded Ware (CW) groups (Battle Axe Culture), which appeared at this time exhibit genetic ancestry from European CW groups that migrated into Scandinavia but also exhibit admixture from farmers, such as the TRB (Egfjord et al. 2021; Malmström et al. 2019).

While aDNA data can reveal long time-scale demographic developments and mobility, strontium isotopes $\left({ }^{87} \mathrm{Sr} /{ }^{86} \mathrm{Sr}\right)$ 
allow us to trace movement on an individual basis and short time scale of both humans and animals (Bentley 2006; Ericson 1985; Montgomery 2010). The data enable us to discuss various kinds of mobility patterns, networks and population dynamics (Brusgaard et al. 2019; Frei et al. 2015; Frei et al. 2019a; Gron et al. 2016; Knipper 2011; Montgomery and Evans 2006; Sjögren et al. 2009). The strontium (Sr) isotope ratios in humans mirror the isotope composition of bioavailable $\mathrm{Sr}$ in the area where people resided, assuming that they consumed locally procured water and food. Strontium isotopes can therefore only be used to trace mobility if the $\mathrm{Sr}$ isotope ratios differ between the areas where the movement took place (Bentley 2006; Montgomery 2010).

In Neolithic and Early Bronze Age Sweden, important social changes coincide with the two phases of megalithic grave construction and use, c. 3400-2600 and 2200-1100 cal BC (Blank et al. 2020). The focus of this study is Falbygden, in the inland of southwestern Sweden (Fig. 1). Here, one of northern Europe's largest concentrations of megalithic graves occurs. The term Falbygden is here used in an expanded sense and encompasses the entire Cambro-Silurian sedimentary zone, which is surrounded by Precambrian crystalline rocks. Previous research (Blank et al. 2018a; Blank and Knipper in press; Sjögren et al. 2009; Sjögren and Price 2013a) has demonstrated a clear distinction between the $\mathrm{Sr}$ isotope ratios in the Cambro-Silurian and the Precambrian regions. Thus, the geological conditions of Falbygden provide an ideal setting for mobility studies based on $\mathrm{Sr}$ isotopes. A recent $\mathrm{Sr}$ isotope baseline (Blank et al. 2018a) of the inland of southwestern Sweden allows more elaborate discussions of mobility patterns. Furthermore, the calcareous soils are favourable for bone preservation, and a remarkable assemblage of wellpreserved archaeological animal and human remains has been recovered from the megalithic graves.

The Middle Neolithic (3350-2200 cal BC) passage graves in the region, characterized by chambers with perpendicular
Fig. 1 Map with the location of Falbygden. A Falbygden, B

Kinnekulle, and $\mathbf{C}$ Halle and Hunne mountains

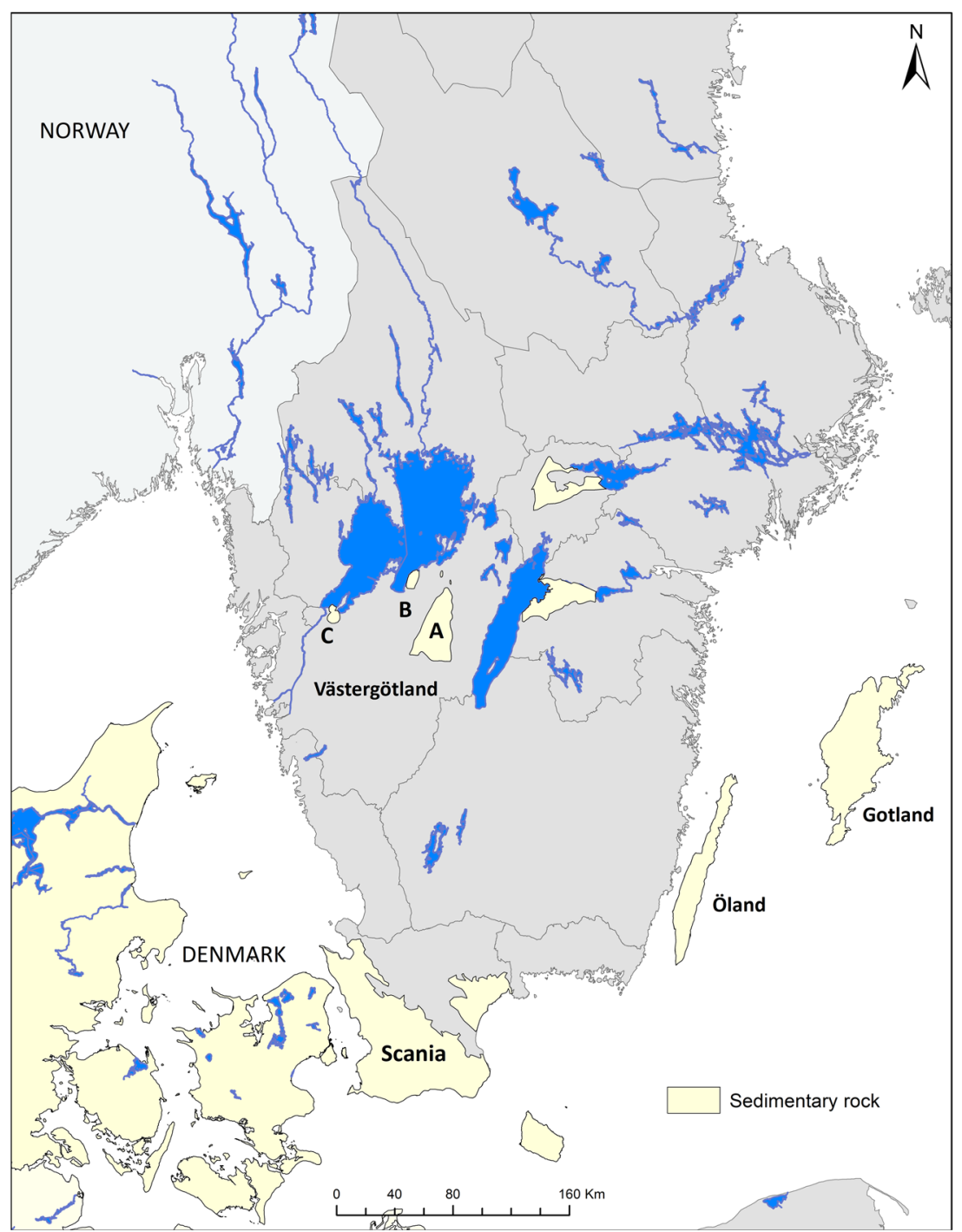


passages, have been extensively studied. The human and animal remains have been submitted to various scientific analyses, such as osteology, aDNA, ${ }^{14} \mathrm{C}$ dating, carbon $(\mathrm{C})$, nitrogen (N), Sr and sulphur (S) isotope analysis (Ahlström 2009; Hinders 2011; Lidén 1995; Linderholm 2008; Malmström et al. 2019; Persson and Sjögren 1995, 2001; Sjögren 2003, 2011, 2015a, 2017; Sjögren et al. 2009; Sjögren and Price 2013a, b; Skoglund et al. 2012, 2014; Rascovan et al. 2019). Most of these studies support a population in Falbygden as being part of a much larger system of exchange/alliances with the surrounding Precambrian regions, involving both humans and cattle.

The skeletal remains from the gallery graves on the other hand, encompassing a wide range of chamber forms constructed by stone slabs, mainly assigned to the Late Neolithic, have not been investigated to their full potential. Only a few studies including ${ }^{14} \mathrm{C}$ dates, $\mathrm{C}, \mathrm{N}$ and $\mathrm{Sr}$ isotopes have been published (Blank 2019; Blank et al. 2018b, 2020; Blank and Knipper in press). More variable isotope data (Blank 2019; Blank et al. 2018b; Blank and Knipper in press) have suggested an increased human mobility during the Late Neolithic compared to the Middle Neolithic.

In this study, we investigate human mobility patterns in the Scandinavian Neolithic and Early Bronze Age in a large set of individuals from numerous megalithic graves in southwestern Sweden. The aim is to investigate population dynamics of the Neolithic and Early Bronze Age megalithic population in the Falbygden area by applying $\mathrm{Sr}$ isotope analysis combined with archaeological and bioarchaeological data, including genetic sex assessment and mitochondrial DNA (mtDNA) haplogroups.

We present the results of $170 \mathrm{Sr}$ isotope measurements of 169 teeth from 141 individuals recovered in 21 megalithic graves of different types (Supplementary Material 1 and 2). In order to cover both main phases (c. 3400-2600 and 2200$1100 \mathrm{cal} \mathrm{BC}$ ) of megalithic burial, 94 new samples mainly from gallery graves were analysed and combined with 77 previously published results (Blank and Knipper in press; Sjögren et al. 2009). Furthermore, we contrasted mtDNA haplogroups from 46 (40 not published before) individuals from ten of the graves to the $\mathrm{Sr}$ isotope data to evaluate possibly related mobility patterns. Strontium isotope compositions of teeth from all sites were compared with various parameters such as chronology, grave type, location, age at death and sex.

Some of the key questions addressed are: What kind of mobility can be presumed? Do mobility patterns vary between males and females or between individuals belonging to different maternal lineages? Are there any shifts in mobility over time? Can the mobility patterns be connected to general migration trends and cultural transformations? Furthermore, we investigate whether there was variation in mobility and discuss possible social drivers behind these patterns.

\section{Background}

\section{Archaeological background}

In present-day Sweden, megalithic graves (dolmens and passage graves) were first constructed around $3400 \mathrm{cal} \mathrm{BC}$, in the cultural setting of the TRB (Blank et al. 2020; Persson and Sjögren 1995; Schulz Paulsson 2010, 2017; Sjögren 2011). The spread of the TRB complex led to extensive cultural transformations, including new subsistence practices (farming and animal husbandry), the construction of causewayed and palisade enclosures, megalithic graves, ritual depositions in wetland and a new set of artefacts, such as TRB pottery and polished axes (Sjögren 2003). In the Middle Neolithic A (3350-2800 cal BC), Pitted Ware Culture (PWC) groups with different burial practices, and subsistence strategies more reliant on marine resources occurred mainly in the coastal areas where they coexisted with TRB groups (Eriksson et al. 2008; Fraser et al. 2018a; Skoglund et al. 2012, 2014). In the following period, Middle Neolithic B (2800-2200 cal BC), the PWC continued, and the Battle Axe Culture (BAC) appeared in Sweden. People of this period buried their dead in single or double flat graves (Edenmo 2008; Malmer 1962, 2002), and megalithic graves were not constructed in most parts of Sweden (Blank et al. 2020). Gallery graves mark a second phase of megalithic building activities. They were mainly constructed during the Late Neolithic and used into the Early Bronze Age (Blank et al. 2020). Gallery graves are distributed over a larger geographical area than the passage graves; they are more common in inland areas and are also found in more northerly regions of Scandinavia.

Gallery graves in southwestern Sweden stand out with their relatively large size and construction details such as port-holes and portal stones (Weiler 1994). In the Late Neolithic, new areas were settled, and increased social complexity, growing population density, cultural blending and stronger reliance on agriculture have been suggested (Apel 2001; Artursson 2009; Iversen 2015; Kristiansen and Larsson 2005; Lekberg 2002; Prescott 2005; Tornberg 2018; Vandkilde 1996). The period is also associated with complex bifacial flint-working techniques, the continued development of long-house construction, intensified import of gold and copper artefacts, and more extensive exchange networks (Apel 2001; Artursson 2009; Kristiansen and Larsen 2005; Ling et al. 2014; Prescott 2005; Simonsen 2017; Vandkilde 1996). The long-distance trading networks and connections to continental Europe increased further in the Early Bronze Age, especially linked to metal trade (Vandkilde 1996, 2016).

According to recent research, the megalithic graves in Sweden were predominantly used for successive inhumations of whole bodies, although cremations sometimes appeared, and some variation in the treatment of the dead occurred (Ahlström 2009; Hollund et al. 2018; Sjögren 2015a, b; 
Strömberg 1968; Weiler 1994). Even though up to 100 inhumations have been confirmed both in passage and gallery graves, these are considered to represent only part of the population (Ahlström 2009; Lennblad 2015; Retzius 1899; Sjögren 2003). The mix of sexes and wide age range of the individuals found corresponds to a cross section of a population, and it has been argued that these graves have been used for families and groups from nearby settlements (Ahlström 2009; Sjögren 2003; Weiler 1994).

In the $50 \times 30 \mathrm{~km}$ region of Falbygden, the concentration of megalithic graves is particularly high. Of the more than 550 identified dolmens and passage graves in Sweden, 254 passage graves and at least four dolmens are known in Falbygden. Of the approximately 2000 gallery graves, 125 have been found in Falbygden. Furthermore, approximately 80 megalithic graves of unknown type have been registered (Blank 2016; Persson and Sjögren 2001; Sjögren 2003: 81). There are no confirmed Middle or Late Neolithic flat graves in the area. However, Sahlström (Sahlström 1932: 32f) documented a few flat graves, which most likely can be ascribed to the BAC. Additionally, a couple of Early Neolithic (4000$3350 \mathrm{cal} \mathrm{BC}$ ) wetland depositions of human remains have been recovered from bogs in Falbygden (Sjögren et al. 2017), and a few stray finds of human remains have been identified at Middle Neolithic settlements (Sjögren et al. 2019). Thus, almost all the Neolithic skeletal remains recovered from this area derive from megalithic graves.

Artefacts of flint and amber in the dolmens and passage graves support exchange with Scania and maybe even Denmark in the Early Neolithic/Middle Neolithic (Anderbjörk 1932; Axelsson et al. 2015; Ebbesen 1996; Sjögren 2003). Both raw materials are also present in the Late Neolithic. Flint daggers imported from the Danish isles and Scania, as well as bronze and gold artefacts dated to the Late Neolithic/Early Bronze Age with origins in Northern or Central Europe, appear in the gallery graves (Apel 2001; Blank 2017; Blank and Knipper in press; Weiler 1994).

\section{Strontium isotopes in archaeology}

Biologically available $\mathrm{Sr}$ originates mainly from weathering rock minerals. Strontium has four naturally occurring stable isotopes, and the ratio between ${ }^{87} \mathrm{Sr}$ and ${ }^{86} \mathrm{Sr}$ is used in provenance research. The isotope ratio of the bioavailable Sr largely reflects the local geology and depends on the type and age of bedrock (Faure 1986), although, e.g. overlaying soil deposits, sea spray, heavy rain and atmospheric dust also contribute (Bentley 2006; Faure 1986; Montgomery 2010). The Sr passes through soils and water into the biosphere and enters the food chain and the human skeleton with minimal isotope fractionation (Bentley 2006). Sr isotope ratios of human and animal teeth average the bioavailable ${ }^{87} \mathrm{Sr} /{ }^{86} \mathrm{Sr}$ ratios of the home range of the respective individuals in their early life
(Bentley 2006). Using Sr isotopes to identify non-local individuals assumes that drinking water and food were procured locally (Montgomery 2010:325). As the Sr concentrations are higher in plants than in animals, plant-based food is the main contributor to Sr uptake in humans, while meat contributes less (Bentley 2006:154). Watts and Howe (2010) reported that the typical adult human body content of $\mathrm{Sr}$ is $0.3-0.4 \mathrm{~g}$, of which $99 \%$ is stored in the skeleton, and the primary sources are grains, leafy vegetables, drinking water and dairy products.

$\mathrm{Sr}$ isotope analysis has become a standard method for studying human and animal mobility and has provided new insights into prehistoric socio-dynamics (Gron et al. 2015, 2016; Fraser et al. 2018b; Frei et al. 2015, 2019b; Knipper 2011; Knipper et al. 2017; Montgomery and Evans 2006; Oelze et al. 2012; Price et al. 2004; Sealy et al. 1995; Sjögren and Price 2013a; Snoeck et al. 2020). Strontium isotope analysis can only trace the first generation of settlers, and the samples only reflect a specific period of the individuals life span, depending on the type of sample, bone or enamel from different teeth (Montgomery 2010:326). In cases where considerable proportions of marine food have been consumed, a shift in the isotopic ratio towards the seawater ratio (0.7092) can be expected (Bentley 2006). Moreover, it should be kept in mind that mobility can only be detected if the $\mathrm{Sr}$ isotope ratios differ between the areas were the movement took place. Thus, residential changes between Falbygden and other areas with similar $\mathrm{Sr}$ isotope ratios cannot be detected. The effectiveness of the method depends on the geological conditions of the study areas as well as the questions asked. Geological information and baseline or comparative data are required to evaluate the results.

\section{Geology and Sr isotope baseline ranges}

Most of southwestern Sweden consists of Precambrian crystalline bedrock from the Early and Middle Proterozoic eras (Andersson et al. 1999; Larsson and Tullborg 2015). However, parts of the landscape are dominated by younger rocks with different formation histories, including three areas of Palaeozoic sedimentary rocks (Falbygden, Kinnekulle, and Hunne and Halle mountains), among which Falbygden is the largest (Fig. 1). Here, the sedimentary succession includes limestone, shale and slate of Cambrian, Ordovician and Silurian ages on top of Lower Cambrian sandstone. These rocks are partly intruded by horizontal layers of diabase, which now form the tops of table mountains (Larsson and Tullborg 2015).

Tectonic and glaciogenic events also shaped the complex geology of western Sweden. They add to the complexity of bioavailable $\mathrm{Sr}$ and may affect/mask the isotope ratios that are otherwise characteristic of the local bedrocks. For example, 
most terrains are covered by glacial deposits (moraines) or by marine and ice lake sediments of variable thickness.

This investigation builds on a recently published Sr isotope baseline study of inland southwestern Sweden (Blank et al. 2018a). It confirmed that the different proxies for the isotope composition of the bioavailable $\mathrm{Sr}$ in general mirror the basement geology, although some effects of glacial transport, overlying sediments and local intrusions of younger rocks were observed. Furthermore, the raw data as well as baseline models conducted with geographic information systems (GIS) differentiate among several areas with restricted isotopic ranges that may, however, partly overlap. The highest $\mathrm{Sr}$ isotope values occur in the geologically oldest eastern parts of the Precambrian area, while the lowest ratios occur in the youngest Palaeozoic sedimentary terrains (Fig. 2). According to the baseline model proposed by Blank et al. (2018a), the low ${ }^{87} \mathrm{Sr} /{ }^{86} \mathrm{Sr}$ ratios of Falbygden extend towards the south-southwest, which corresponds with the general direction of movement of the glacial ice in this region (Påsse and Pile 2016).

The baseline model was based on water samples from streams, creeks and springs as well as some teeth of small animals (Blank et al. 2018a). As the study area has not been affected by any major environmental/geological changes since prehistory, we assumed that the $\mathrm{Sr}$ isotope composition of the modern samples would provide a valuable proxy for the bioavailable strontium in the past and help investigating prehistoric human mobility. However, a recent study has raised some concerns regarding alteration of the $\mathrm{Sr}$ isotope ratios of surface water due to agricultural lime applied in modern times (Thomsen and Andreasen 2019). Frei et al. (2019a, b) criticized their conclusions and demonstrated that agricultural lime is retained in the upper organic-rich layers of respective soil profiles over decades and does not seem to enter the ground water.

Falbygden is an area with calcareous bedrock, which makes liming of fields and lakes unnecessary. However, it may have been practised in the areas of crystalline bedrock around Falbygden. Sampling for the baseline study of inland southwestern Sweden avoided modern agricultural areas (Blank et al. 2018a). If the $\mathrm{Sr}$ isotope ratios of the Precambrian regions would have been biased by Sr from agricultural lime, then the differences between the isotope ratios of the sedimentary area of Falbygden and the surrounding Precambrian regions would originally have been even greater than today. For a discussion regarding potential problems with modern-day liming, see Supplementary Material 3.

\section{Ancient DNA in archaeology}

DNA is a molecule composed of two polynucleotide chains that spiral around each other to form a double helix carrying genetic instructions for the development, functioning, growth and reproduction of all known organisms and many viruses. Ancient DNA originates from ancient specimens and is more degraded compared to contemporary genetic material. In the last 30 years, the development of extracting and amplifying aDNA has become an important and recognized method of investigating certain archaeological issues. Ancient DNA from human remains can provide us with information concerning biological sex, genetic inheritance, family relations, population history and diseases. A large body of recent research based on prehistoric human remains have applied aDNA analysis to address questions related to biological sex (e.g. Hedenstierna-Jonson et al. 2017), kinship and social
Fig. 2 Strontium isotope baseline model of inland southwestern Sweden, based on Blank et al. 2018a. The model is based on 89 water and non-domestical faunal samples. 1 Halle and Hunne mountains, 2 Kinnekulle, and 3 Falbygden

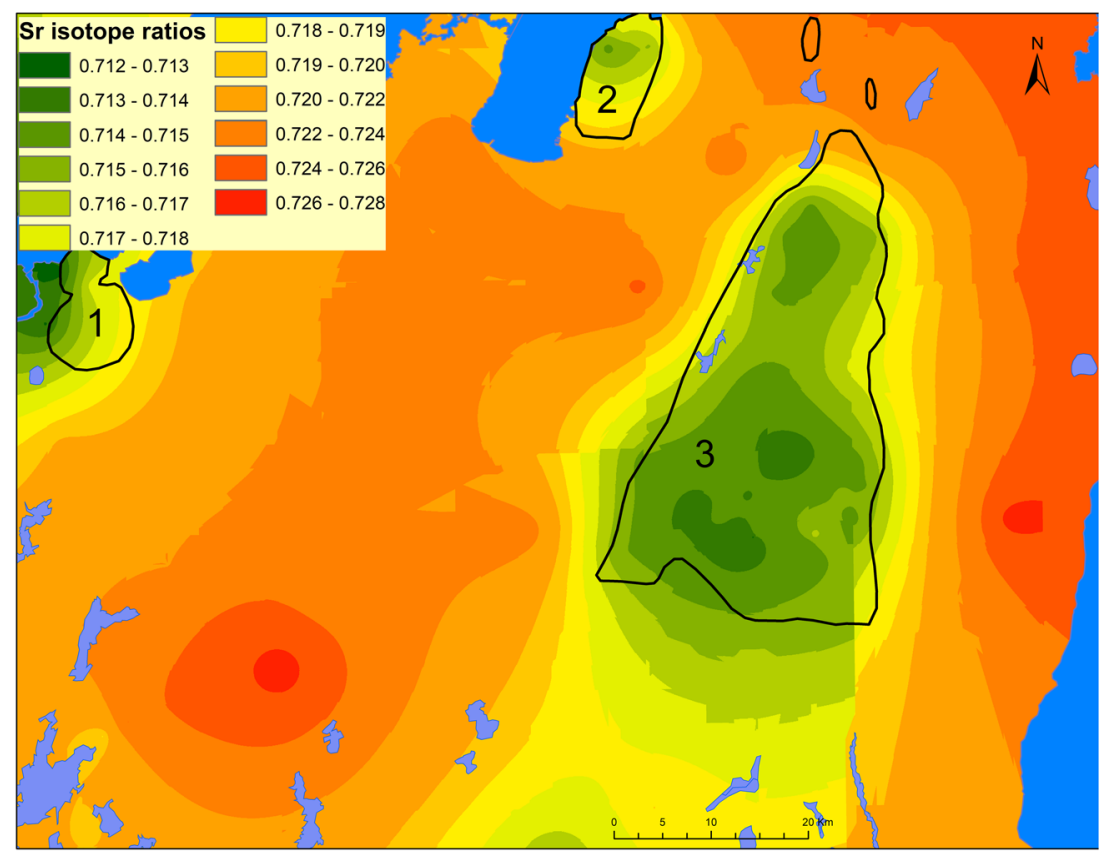


organization (e.g. Cassidy et al. 2020; Sánchez-Quintoa et al. 2019; Schroeder et al. 2019; Sjögren et al. 2020), diseases (e.g. Rascovan et al. 2019), mobility and demographic developments (e.g. Allentoft et al. 2015; Haak et al. 2015; Malmström et al. 2019; Skoglund et al. 2012, 2014). In this study we included mtDNA and sex assessment data, while the nuclear aDNA is presented in a larger ongoing study primarily focusing on general demographic trends.

There are two kinds of DNA: chromosomal DNA/nuclear DNA, which is found in the cell nucleus, and mitochondrial DNA (mtDNA), which is found outside the nucleus in the mitochondria. Human nuclear DNA consists of 46 chromosomes, composed of 22 pairs of autosomal chromosomes and one pair of sexual chromosomes. The two possible combinations of sexual chromosomes are XX (female) and XY (male). The Y chromosome can only be inherited from males to sons. The mtDNA can only be passed on by the mother to an offspring and can be used to establish relatedness on the matrilineal side. Haplotypes are a combination of sequence variants derived via mutations from an ancestral sequence. Haplotypes which have a similar origin can be arranged in haplogroups. Human Y chromosomal and mtDNA haplogroups can tell us about inheritance on a personal level, and as these groups are unequally distributed around the globe, they can also be used for investigating population dynamics in the past (Bramanti 2013).

\section{Material and method}

\section{Sampling strategy and selection criteria}

This study is mainly based on molars, and in a few cases on other teeth. The main selection criterion was preservation, so that $\mathrm{Sr}$ isotope analysis could be conducted on the enamel and ${ }^{14} \mathrm{C}$ dating; carbon and nitrogen stable isotope measurements as well as aDNA analysis could be done on the dentine from the same tooth (aDNA is best preserved in teeth and petrous bone). In addition, the teeth were analysed for oxygen isotopes which is reported in a separate publication. As these are all destructive analyses, our intention was to use as little material as possible. Second molars were prioritized over third molars, where enamel forms later and over a longer time. Unless no additional material for nitrogen isotope analysis was available, first molars were avoided, as the $\delta^{15} \mathrm{~N}$ value may be biased by breastfeeding (Hillson 1996). Our strategy was to sample as many unique individuals as possible without sampling the same individual multiple times. We therefore adjusted the sampling according to the availability of different parts of jawbones from the commingled and fragmented skeletal remains in the specific graves. In a few graves, where possible, we sampled two or three molars from the same individual to be able to detect possible movements during childhood and early adolescence. In the comparative $\mathrm{Sr}$ isotope analyses when only one tooth per individual was included, we selected the measurement from the M2 (if M2 was missing we included the M1 or M3 instead).

For $\mathrm{Sr}$ isotope analysis, we sampled enamel from human teeth. Enamel is less susceptible to diagenesis and contamination than bone and is therefore favoured in human and animal mobility investigations (Bentley 2006:167). Unlike bone that continuously undergoes chemical and structural turnover, enamel remains stable after its formation. In humans, enamel mineralizes between infancy and early adolescence, and the time spans vary depending on tooth type (Hillson 1996; Nelson and Ash 2010: 31). Usually teeth with late crown formation, including second (2.5-8 years) or third (7-16 years) molars or premolars (1.5-7 years), but also earlier forming teeth, such as first molars (0-3 years), incisors (3 months -5 years), and canines (4 months-7 years), may be sampled (Nelson and Ash 2010: 31). Deciduous teeth, which start to form during the prenatal stage, reflect a combination of the mothers' and child's isotopic uptakes (Nelson and Ash 2010: 31). Enamel mineralization may take several years, which means that the measured $\mathrm{Sr}$ isotope ratios of our bulk samples represent an average of the Sr which has been incorporated during this time (Montgomery 2010:330). In humans, the formation and mineralization of enamel and fixation of the ${ }^{87} \mathrm{Sr} /{ }^{86} \mathrm{Sr}$ are still not completely understood (Montgomery and Evans 2006). However, the general tooth formation is known, and by micro-sampling a specific tooth, the obtained data will follow a timeline which can be assessed in terms of the specific age of the individual during a limited period (Goodman et al. 1980). We did not have the possibility of sampling on a micro-scale, and instead all the enamel samples were measured in bulk.

Averaging the enamel of complete tooth crowns implies that if a person moved to a new location with different geological conditions after or during enamel formation, the $\mathrm{Sr}$ isotope ratios of the enamel will differ from the isotopic ratio of the new location, assuming local food was consumed. Mixed isotope ratios of bulk samples that represent strontium from different sources may differ from the ${ }^{87} \mathrm{Sr} /{ }^{86} \mathrm{Sr}$ range of the bioavailable $\mathrm{Sr}$ at each single location. Temporally higher resolved data regarding prehistoric animal and human mobility can be obtained by sampling multiple teeth with different mineralization periods from the same individual, or by serial sampling of the same tooth crown, mainly conducted for animal teeth (Gerling et al. 2017; Glykou et al. 2018; Lewis et al. 2014).

\section{Local and non-local Sr isotope ranges}

In this study, baseline ranges are suggested based on the previous study (Blank et al. 2018a). The ranges are intended as guidance. Due to the complexity of the geological history of 
southwestern Sweden, the isotopic ranges are set in a conservative manner.

In some previous publications, local ranges have been quantified by using the mean value and standard deviation (1 or 2 sigma) of the $\mathrm{Sr}$ isotope ratios of the investigated material (Evans et al. 2010; Fraser et al. 2018b; Frei and Frei 2011, 2013; Price et al. 2002). In this case, the datasets are not always normally distributed, and therefore, mean values and standard deviations are not necessarily adequate. Instead, we consider that the whiskers of boxplots are better estimates of the respective baseline ranges. The whiskers represent 1.5 quartile ranges from the 25th or 75 th percentile, unless the $\mathrm{max} / \mathrm{min}$ values are within this range, in which case these are used. Outliers are defined as values falling outside the whisker range (Fig. 3). The outliers are considered to represent either non-local fauna and/or very localized anomalies. In any case, due to averaging of $\mathrm{Sr}$ of different sources within human food chains, these outliers are probably not very representative for estimating the $\mathrm{Sr}$ isotope ranges of locally grown-up humans.

According to Fig. 3, the Precambrian area of southwestern Sweden shows ${ }^{87} \mathrm{Sr} /{ }^{86} \mathrm{Sr}$ values of 0.715 to 0.728 . These geological formations can be subdivided into the Sveconorwegian west: ${ }^{87} \mathrm{Sr} /{ }^{86} \mathrm{Sr}=0.720$ to 0.722 ; the Sveconorwegian east: ${ }^{87} \mathrm{Sr} /{ }^{86} \mathrm{Sr}=0.715$ to 0.728 ; and the Transscandinavian granite-porphyry belt: ${ }^{87} \mathrm{Sr} /{ }^{86} \mathrm{Sr}=0.722$ to 0.728 . Ratios
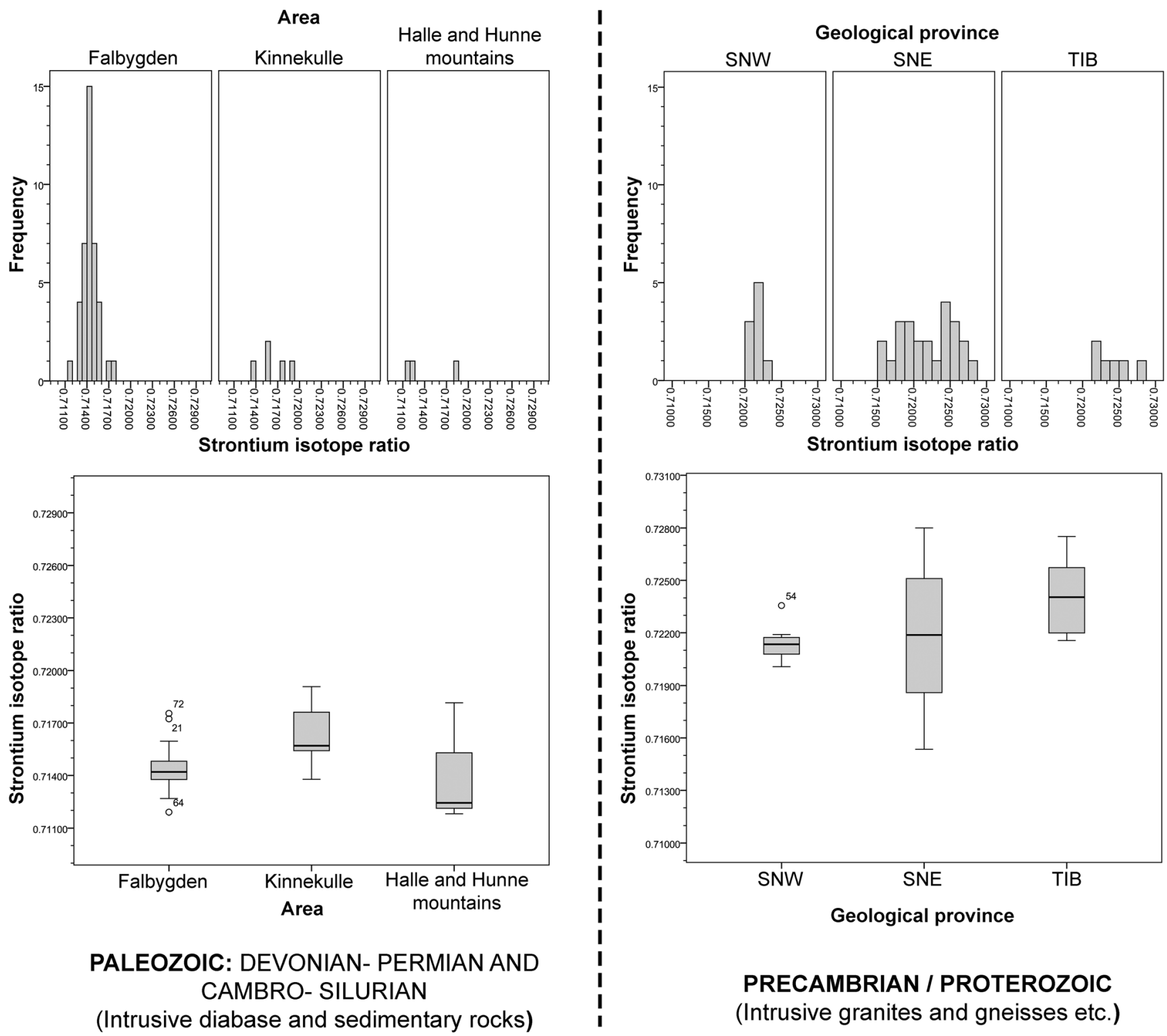

\section{PRECAMBRIAN / PROTEROZOIC (Intrusive granites and gneisses etc.)}

Fig. 3 Overview of $\mathrm{Sr}$ isotopes ratios of water and animal samples from different Palaeozoic and Proterozoic provinces presented by histograms and boxplots, from Blank et al. 2018a (Fig. 9). SNW, Sveconorwegian West; SNE, Sveconorwegian East; TIB, Transscandinavian granite-porphyry belt 
above 0.726 are rare and more likely to be found in the eastern part of the studied area. The lower ratios 0.715 to 0.717 are only found south of Falbygden.

In the Palaeozoic areas, the baselines range from ${ }^{87} \mathrm{Sr} /{ }^{86} \mathrm{Sr}$ $=0.712$ to 0.719 . These areas can be further divided into Falbygden ${ }^{87} \mathrm{Sr} /{ }^{86} \mathrm{Sr}=0.713$ to 0.716 ; Kinnekulle: ${ }^{87} \mathrm{Sr} /{ }^{86} \mathrm{Sr}$ $=0.714$ to 0.719 ; and Halle and Hunne mountains: only represented by three reference samples which yielded ${ }^{87} \mathrm{Sr} /{ }^{86} \mathrm{Sr}$ $0.712,0.712$ (from diabase) and 0.718 (from sandstone).

To illustrate the variation of the baseline values within Falbygden, we choose to use the interpolated surface model (Blank et al. 2018a: Fig. 11). We divided the isotope ratios into 12 classes in order to get a detailed division of different isotopic zones (Fig. 4), which should be considered preliminary. Supplementary and denser sampling of the bioavailable Sr would be required to facilitate studies of mobility patterns within Falbygden. Statistical tests revealed no significant difference between samples from any of the rock types in Falbygden (Blank et al. 2018a). On the other hand, both statistical tests of the reference data and the interpolated surface models demonstrate that higher ratios occur in the northern area and along the eastern and western borders of Falbygden (Blank et al. 2018a; Fig. 4).

Local ranges for the studied sites were defined and are referred to as "site local". These ranges were supposed to reflect the ratios in a very limited area surrounding the sites. Archaeological research in Falbygden has demonstrated that settlements with associated farmland were located close to the megalithic graves $(100-500 \mathrm{~m})$ in the Middle Neolithic (Sjögren 2003; Sjögren et al. 2019). In contrast, the locations of Late Neolithic settlements are less well-known. However, they seem to be placed close to the graves although a larger variation of distances is probable (Axelsson 2010; Sjögren 2003; Weiler 1994). Therefore, the site local range is defined as the area within a radius of $1 \mathrm{~km}$ from the burial sites (Fig. 4). The site local ranges, as well as the other ranges, were based on interpolated and not raw data. In the baseline study (Blank et al. 2018a), two interpolated surface models were presented. The differences in the ratios at the burial sites in the two models vary between 0.0008 and 0.0000 . Thus, three decimals seem to provide a reasonable resolution of the site local baseline ranges. So, the local ranges of the sites were rounded up or down to three decimal places.

According to the interpolation (Fig. 4) as well as the statistics presented in Blank et al. 2018a, the local range of Falbygden is set at ${ }^{87} \mathrm{Sr} /{ }^{86} \mathrm{Sr}=0.713$ to 0.716 . This range is referred to as "Falbygden local". As it is not possible to trace movement between locations with similar $\mathrm{Sr}$ isotope baseline ranges, it would be difficult to identify people moving in from Kinnekulle, for example, that has a partly overlapping baseline range with Falbygden. Other sedimentary areas with overlapping isotope ranges include terrains east of lake Vättern as well as the Baltic islands of Gotland and Öland (Eriksson et al. 2016; Fornander et al. 2015; Fraser 2018: 61; Wilhelmson and Ahlström 2015; Wilhelmson and Price 2017).

Ratios between 0.716 and 0.718 are referred to as "semilocal" to Falbygden. Such ratios are found in the northeastern, northwestern and northern borders of Falbygden, and also south of it, and may reflect residence there. Individuals displaying $\mathrm{Sr}$ isotope ratios within this span could also be people that have moved between Falbygden and the surrounding Precambrian regions during the time of enamel mineralization. Ratios within this range may also be
Fig. 4 Interpolated surface model manually classified into 12 groups, based on Blank et al. 2018a. Numbers represent the studied graves (see

Supplementary Material 1,2) and the circles the $1-\mathrm{km}$ radius defining the "site local" areas. Black squares, passage graves; red square, passage grave/gallery grave; yellow dots, gallery graves; and purple dot, gallery grave/dolmen

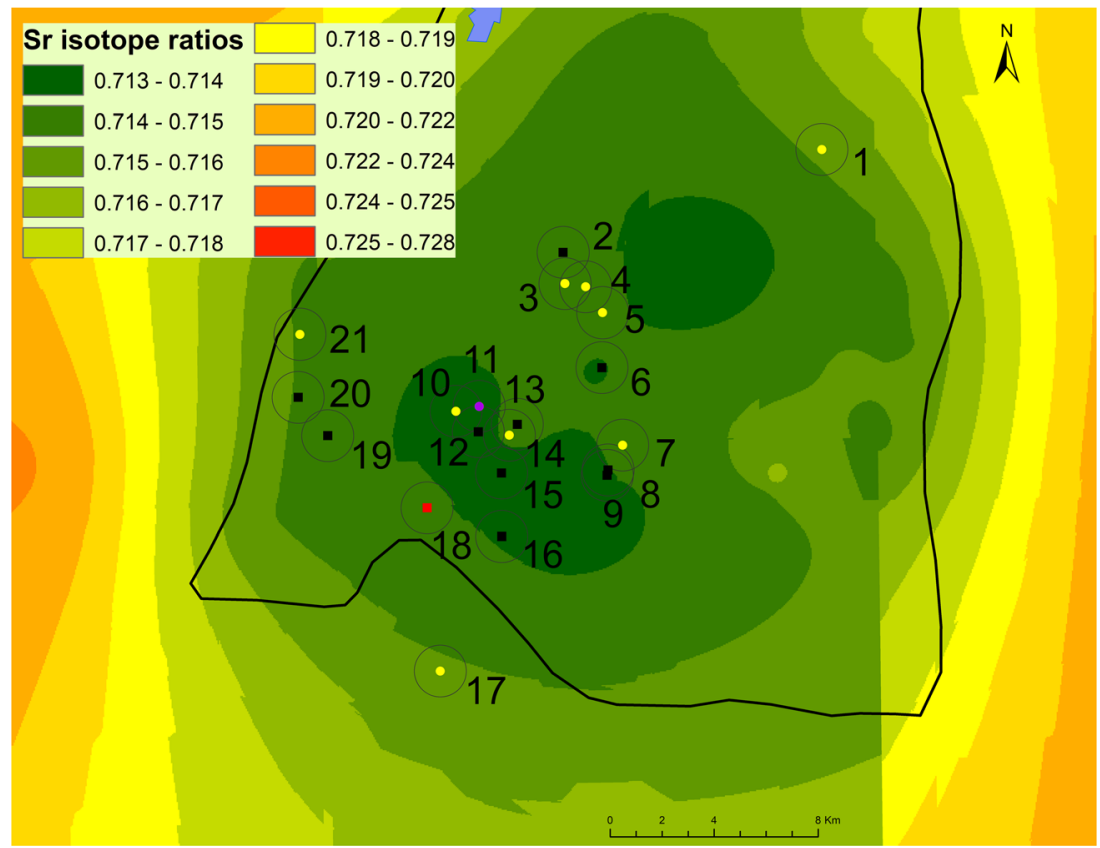


achieved by other means, which is further elaborated on in the discussion.

The Sr isotope ratios expected in the Precambrian regions of inland southwestern Sweden, excluding the area south of Falbygden, are estimated to fall between 0.718 and 0.726 , with the lowest ratios nearest to the sedimentary areas (Fig. 3). This range is referred to as "non-local (VG)", as these ratios are found in the Västergötland (VG) region of inland southwestern Sweden. Other areas further away display similar ratios, for example, Norway and the island of Bornholm, Denmark (Frei and Frei 2013; Price and Naumann 2015). Furthermore, similar ratios can be suspected in regions with similar bedrock such as Småland and parts of Scania in southern Sweden.

Sr isotope ratios above 0.726 and below 0.712 are referred to as "non-locals (outside VG)". Higher Sr isotope ratios than in the southwestern regions of Sweden appear in the eastern and northeastern areas where the oldest bedrock in Sweden is present (Lindström et al. 2000; Loberg 1999), and where some of the highest $\mathrm{Sr}$ isotope values ever measured in water occur (Löfvendahl et al. 1990; Åberg 1995; Åberg and Wickman 1987). Sr isotope ratios lower than 0.712 are found in areas with younger bedrock and/or effected by sea spray, such as the west coast, parts of Scania, Öland, Gotland and Denmark (Arcini et al. 2016; Bergerbrant et al. 2017; Fornander et al. 2015; Fraser 2018:61; Frei and Frei 2011; Frei and Price 2012; Klassen et al. 2020; Sjögren et al. 2009; Wilhelmson and Ahlström 2015).

\section{Sample material}

In total, we included the results from 170 analyses of teeth from 141 individuals from 21 megalithic graves of different types (Table 1). Ninety-four teeth were sampled for this investigation, while the remaining were previously published (Blank and Knipper in press; Sjögren et al. 2009). One of the teeth (MJ20) was sampled twice and analysed for Sr isotope ratios in two separate laboratories (Curt Engelhorn Center for Archaeometry in Mannheim, Germany and Danish Center for Isotope Geology, University of Copenhagen, Denmark). The difference between the results obtained at the two laboratories is $<0.0001$ (Supplementary Material 1).
Most of the sites are located on the limestone plateau in the southwestern part of Falbygden (Fig. 5). However, a few sites are found in terrains where alum shale, slate and sandstone are prevalent. Borgunda 120 is the only grave from the eastern part of Falbygden, while Kinneved 73 is positioned south of Falbygden in the Precambrian area (Fig. 5).

According to the baseline model, eight of the 21 graves are found in areas with isotope ranges between 0.713 and 0.714 , eleven in zones with ratios between 0.714 and 0.715 and two in terrains with isotope ratios ranging from 0.715 to 0.716 (Fig. 4). Considering a 1-km radius from the graves, two sites were located in terrains with Sr isotope ratios from 0.713 to 0.714 , nine in zones with ratios ranging from 0.713 to 0.715 , six in areas with ratios between 0.714 and 0.715 , and four in zones with ratios from 0.714 to 0.716 (Fig. 4; Supplementary Material 2).

The samples are concentrated to two phases (Fig. 6). The first, referred to as the Early Neolithic-Middle Neolithic phase, covers a time span from 3500 to 2600 cal BC, with most samples concentrated to 600 years in the Middle Neolithic A (3400-2800 cal BC). The second phase, defined as the Late Neolithic-Early Bronze Age, extends from 2200 to $1000 \mathrm{cal} \mathrm{BC}$ with the majority of the samples falling within a 400 years span between 2000 and 1600 cal BC. Consequently, the comparisons conducted in this study between the periods might be slightly biased by the uneven distribution of samples between these two main phases and by the different duration. A higher number of samples from the Late Neolithic-Early Bronze Age ( $n: 81)$ could result in a higher variation of $\mathrm{Sr}$ isotope ratios and mtDNA haplogroups compared to the Early Neolithic-Middle Neolithic ( $n: 60)$. On the other hand, the longer duration of the Middle Neolithic phase may also have caused larger variation of $\mathrm{Sr}$ isotope ratios and haplogroups during this period (Fig. 6).

The sampling from megalithic graves shows a chronological gap of at least 400 years (2600-2200 cal BC), when no megalithic graves were constructed or used (Fig. 6, Blank et al. 2020). The absence of human remains from this time span, and the few burials representing 2800-2600 cal BC prevent us from describing a complete picture of the development in the area. Instead, data from the human remains from the two main phases of use are compared.

Tooth roots from 91 individuals (72 of them also sampled for $\mathrm{Sr}$ isotope analysis) were sampled for aDNA analyses. Results from two of the individuals from Valtorp 2
Table 1 Overview of number of sites, individuals and samples

\begin{tabular}{lccccc}
\hline & $\begin{array}{l}\text { Passage } \\
\text { graves }\end{array}$ & $\begin{array}{l}\text { Gallery } \\
\text { graves }\end{array}$ & $\begin{array}{l}\text { Gallery/passage } \\
\text { grave }\end{array}$ & $\begin{array}{l}\text { Gallery } \\
\text { grave/Dolmen }\end{array}$ & Total \\
\hline No. sites & 10 & 9 & 1 & 1 & 21 \\
No. individuals & 63 & 72 & 1 & 5 & 141 \\
No. teeth & 63 & 99 & 2 & 5 & 169 \\
\hline
\end{tabular}


(Rössberga) passage grave were published in Malmström et al. 2019. The data were combined with previously published results from four individuals from Gökhem 94 (Frälsegården) passage grave (Skoglund et al. 2014). Of these, 64 persons could be assigned to biological sex and 46 to specific mtDNA haplogroups (Table 2). The Early and Middle Neolithic individuals with determined mtDNA haplogroups originate from four passage graves and the Late Neolithic and Early Bronze Age individuals from six gallery graves and one passage grave (Supplementary Material 1).

Further information of the sites and samples is found in Supplementary Material 1 and 2.

\section{Osteological and biomolecular analysis}

Several osteologists (Supplementary Material 1) carried out analyses of the human remains, and the analytic methods used are summarized in Supplementary Material 3. DNA extraction and library preparation were conducted in a clean room laboratory dedicated to ancient DNA work. Illumina shotgun sequencing was performed at SciLife SNP\&SEQ platform. Bioinformatics processing, mtDNA analyses and sex assessments were computed using the resources of Uppsala Multidisciplinary Center for Advanced Computational Science (UPPMAX). All aDNA analyses were performed at Uppsala University. The biomolecular methods (sex assessment and mtDNA analyses) are presented in detail in Supplementary Material 3.

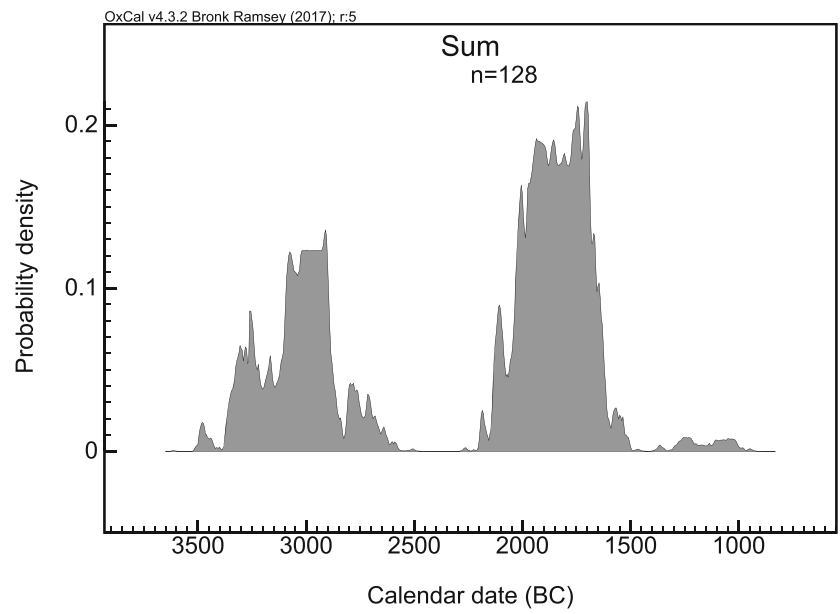

Fig. 6 In total 47 individuals were dated to EN-MN (Early NeolithicMiddle Neolithic) and 81 individuals to the LN-EBA (Late NeolithicEarly Bronze Age). Isotope data of additionally thirteen MN individuals previously published in Sjögren et al. (2009) lacked radiocarbon dates

\section{Isotope analysis}

Analyses of Sr isotopes were conducted at the Curt Engelhorn Center Archaeometry, Mannheim, and the Institute of Geosciences, Applied and Analytical Palaeontology at the University of Mainz in Germany. The procedures for sample preparation and analysis are reported in Supplementary Material 3. Although most radiocarbon dates used in this study were previously published (Blank 2017; Blank et al. 2018b, 2020; Fibiger et al. 2013; Malmström et al. 2019;
Fig. 5 Map with geological classifications and the distribution of the included sites. Numbers corresponds to site numbers in Supplementary Material 1 and 2. Black squares, passage graves; red square, passage grave/gallery grave; yellow dots, gallery graves; and purple dot, gallery grave/dolmen

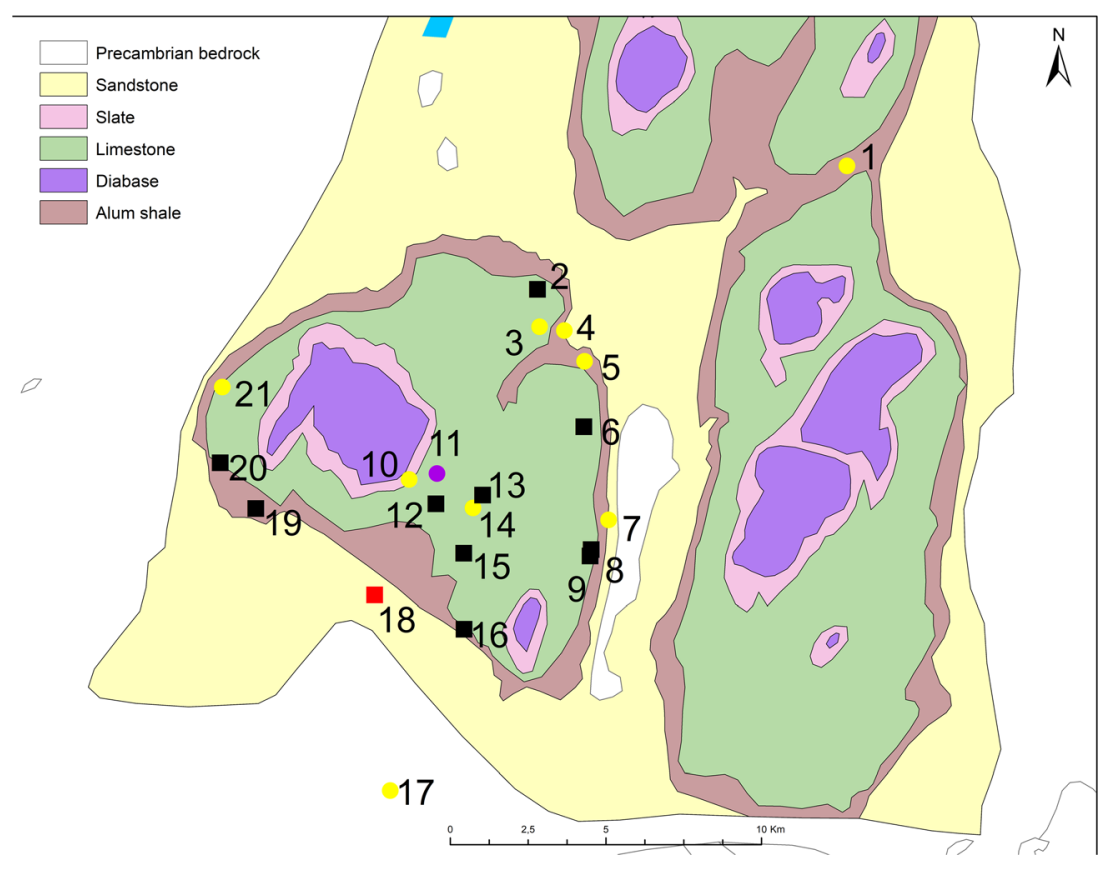


Table 2 Number of aDNA samples and data grouped by radiocarbon dates

\begin{tabular}{llll}
\hline No of individuals & $\begin{array}{l}\text { EN- } \\
\text { MN }\end{array}$ & $\begin{array}{l}\text { LN- } \\
\text { EBA }\end{array}$ & Total \\
\hline Sampled for aDNA & $40+6^{*}$ & 49 & 95 \\
Assigned to biological sex & $24+6^{*}$ & 34 & 64 \\
Assigned to mtDNA haplogroup & $16+6^{*}$ & 24 & 46 \\
\hline
\end{tabular}

*Individuals published in Skoglund et al. 2014 and in Malmström et al. 2019. EN Early Neolithic, $M N$ Middle Neolithic, $L N$ Late Neolithic, $E B A$ Early Bronze Age

Sjögren et al. 2009), three samples from Valtorp 2 passage grave were dated for this study. These ${ }^{14} \mathrm{C}$ analyses are conducted at the Ångström Laboratory, Uppsala University (for more details see Supplementary Material 3).

\section{Statistical analysis}

Statistical analyses were conducted using IBM SPSS version 23 and PAST (PAleontological STatistics) version 3.25. The data evaluation included descriptive statistics, significance tests and diversity measures. As a normal distribution could not be demonstrated in all cases, the nonparametric Mann-Whitney $U$ test was used to examine whether the observed differences were statistically significant at the 5\% level.

Diversity encompasses two aspects: richness and evenness. We used Menhinick D index to investigate the richness of mtDNA haplogroups. Since the larger the sample, the more haplogroups are expected to be found, the number of haplogroups is divided by the square root of the number of individuals in the sample: $\mathrm{D}=\mathrm{s}$ (haplogroups) $/ \sqrt{ } \mathrm{N}$ (individuals). Furthermore, evenness (Shannon $\mathrm{H}$ index) was also calculated. This index measures the dominance or evenness of haplogroups in relation to one another taking the number of samples into account. The lower the $\mathrm{H}$ index, the more uneven distribution of the haplogroups.

\section{Results}

\section{Strontium isotope ratios, an overview}

A general overview of the $\mathrm{Sr}$ isotope analyses from all samples is presented in Fig. 7. The $\mathrm{Sr}$ isotope ratios range between 0.710 and 0.733 . Most Sr isotope ratios fall between 0.714 and 0.718 , whereas ratios below 0.713 and over 0.727 are rare (Fig. 7).

Considering the various local, semi-local and non-local ranges suggested, $35.5 \%$ of the samples fall within the range local to Falbygden $(0.713-0.716), 29 \%$ fall within the semilocal (0.716-0.718), $30.5 \%$ within the non-local (VG) range (0.718-0.726) and 5\% fall in the non-local (outside VG) range below 0.712 or over 0.726 (Table 3 ). Hence, $35.5 \%$ of the teeth are suggested to exhibit Falbygden non-local ratios, while $64.5 \%$ display Falbygden local or semi-local ratios. If only one tooth per individual is counted, similar results are obtained: $35 \%$ non-locals and $65 \%$ locals and semi-locals (Table 3).

In Fig. 8, all results are depicted in a histogram grouped by tooth type. The tooth types represented by more than three specimens occur both in the local and non-local ranges. There are no significant differences between tooth types
Fig. 7 Histogram of ${ }^{87} \mathrm{Sr} /{ }^{86} \mathrm{Sr}$ ratios of all teeth investigated in this study. A Falbygden local range, $\mathbf{B}$ semi-local range, $\mathbf{C}$ nonlocal range to Falbygden found within Västergötland, D non-local range to Falbygden found outside of Västergötland

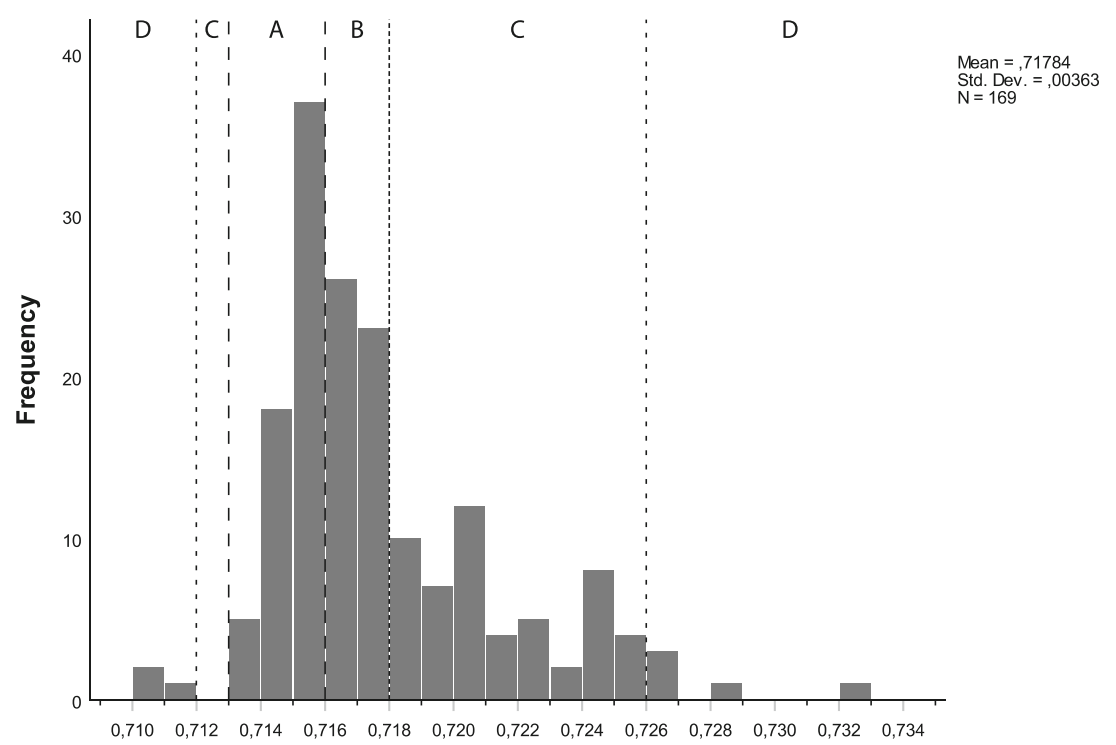

Strontium isotope ratio 
Table 3 Number of samples and individuals within the different $\mathrm{Sr}$ isotope ranges

\begin{tabular}{llllll}
\hline & $\begin{array}{l}\text { Falbygden local } \\
0.713-0.716\end{array}$ & $\begin{array}{l}\text { Semi-local } \\
0.716-0.718\end{array}$ & $\begin{array}{l}\text { Non-local (VG) } \\
0.718-0.726\end{array}$ & $\begin{array}{l}\text { Non-local (outside VG) } \\
<0.712,>0.726\end{array}$ & Total \\
\hline Samples (N) & 60 & 49 & 52 & 8 & 169 \\
Individuals (N) & 52 & 40 & 42 & 7 & 141 \\
\hline
\end{tabular}

(Mann-Whitney $U$ test: permanent-deciduous $p=0.304, \mathrm{M} 1-$ M2 $p=0.506$, M1-M3 $p=0.566$, M2-M3 $p=0.346$ ).

The results of the $\mathrm{Sr}$ isotope analyses are found in Supplementary Material 1 along with basic information about the sites and samples and with radiocarbon dates, mtDNA and osteological data. In Supplementary Material 2, summaries of the results from each grave are found along with descriptions of the sites. In this section, the $\mathrm{Sr}$ isotopes from all sites are compared with various parameters such as time, grave type, location and sex. Furthermore, the mtDNA haplogroups are presented and contrasted to the $\mathrm{Sr}$ isotopes.

\section{Strontium isotope ratios, chronology and grave types}

The following evaluations will consider one tooth per individual in order to achieve comparability between groups. As previously mentioned, the M2 was preferred if available (se method section). The possible interpretations are further developed in the discussion section.

Most of the Early Neolithic II and Middle Neolithic individuals $(28 / 60,47 \%)$ display $\mathrm{Sr}$ isotope ratios that fall within the Falbygden local range, while $21(35 \%)$ exhibit semi-local ratios. Eleven of the 60 burials (18\%) from the older phase display ${ }^{87} \mathrm{Sr} /{ }^{86} \mathrm{Sr}$ ratios $>0.718$, which are non-local to Falbygden. None of them exhibits Sr isotope ratios higher than 0.722 . One Middle Neolithic A individual showed a rather low non-local ${ }^{87} \mathrm{Sr} /{ }^{86} \mathrm{Sr}$ of 0.712 . Two individuals dated to the Middle Neolithic B exhibit the lowest ratios found in this study, 0.710 (Fig. 9).

The Late Neolithic and Late Neolithic/Early Bronze Age inhumations yielded more variable $\mathrm{Sr}$ isotope ratios and comprised more individuals with high non-local values compared to the Early and Middle Neolithic (Fig. 9). The difference between the Early and Middle Neolithic and the Late
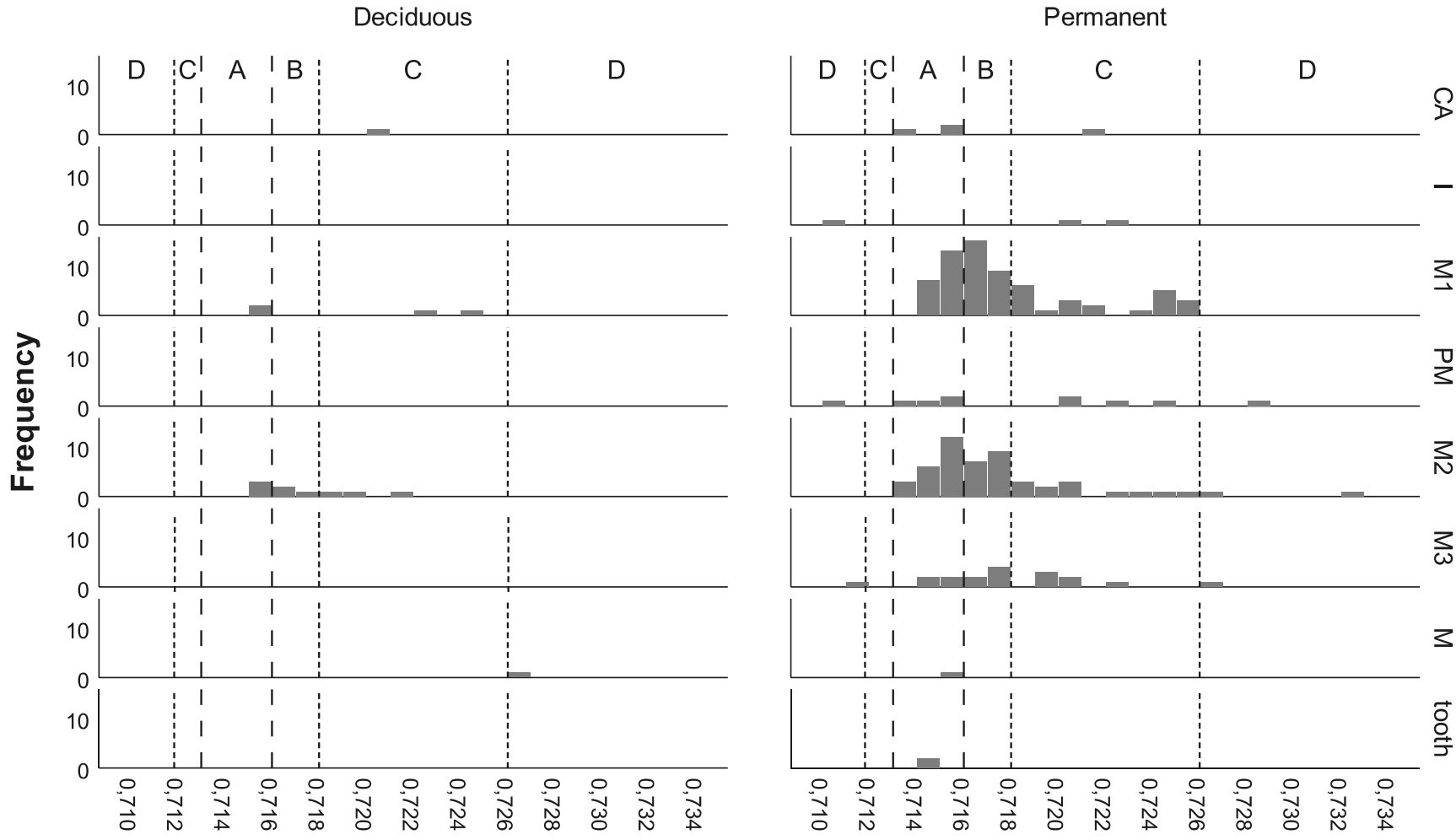

\section{Strontium isotope ratio}

Fig. 8 Histogram of all samples grouped by type of tooth. CA, canine; I, incisor; M, molar; PM, premolar. A Falbygden local range, B semi-local range, C non-local range to Falbygden found within Västergötland, D non-local range to Falbygden found outside of Västergötland 
Neolithic and Early Bronze Age is statistically significant (Mann-Whitney $U$ test, $p=0.000$ ). In the Late Neolithic and Early Bronze Age, 38 of the 79 individuals (48\%) display ratios that fall within the non-local range, and of these, four exhibit ratios higher than 0.726 . Only 22 burials (28\%) display ratios within the local range of Falbygden, while 19 (24\%) exhibit semi-local ratios. The proportion of semi-local individuals is higher in the Early Neolithic/Middle Neolithic than in Late Neolithic/Early Bronze Age (35\% and 24\%).

The three latest burials, two of which can be dated to the Early Bronze Age, have Sr isotope ratios between 0.713 and 0.714 , which agree with the lower range of the local baseline of Falbygden. These samples actually exhibit lower $\mathrm{Sr}$ isotope ratios than any of the Late Neolithic samples, but similar ratios occur during the Middle Neolithic (Fig. 9).

Considering the grave types and particularly the reuse of passage graves in the Late Neolithic, some observations can be made. In the Late Neolithic and Late Neolithic/Early Bronze Age, both locals and non-locals seem to have been deposited in the existing passage graves. The three earliest Late Neolithic burials in Early Neolithic/Middle Neolithic passage graves exhibited highly radiogenic, non-local ratios. During the second part of the Late Neolithic, only individuals with local $\mathrm{Sr}$ isotope ratios are deposited the passage graves
(Fig. 9). The two individuals with the lowest ratios, with a possible origin in Scania, the Swedish west coast or even Denmark, were buried in an atypical grave that might be interpreted as a gallery grave or dolmen (Falköping stad 26). Furthermore, all individuals displaying $\mathrm{Sr}$ isotope ratios between 0.722 and 0.727 were placed in gallery graves.

The Sr isotope data indicate a remarkable change of mobility patterns over time with peaking occurrences of non-local Sr isotope ratios in the second part of Late Neolithic, in which individuals with high radiogenic values dominate $\left({ }^{87} \mathrm{Sr} /{ }^{86} \mathrm{Sr}>\right.$ 0.722 ).

\section{Strontium isotopes and placement of the dead}

Burials from both main periods occur in several passage graves. The only sample from the surrounding mound belongs to a Bronze Age male (Fig. 10). Among the individuals in the chambers were locals to Falbygden, semi-locals and non-locals. In contrast, seven of eight individuals recovered either from the mound, in the entrance area or in the passage, yielded ${ }^{87} \mathrm{Sr} /{ }^{86} \mathrm{Sr}$ ratios within the local range of Falbygden (Fig. 10). Due to poor documentation and later disturbances, the exact original positions of the skeletons are rarely known.

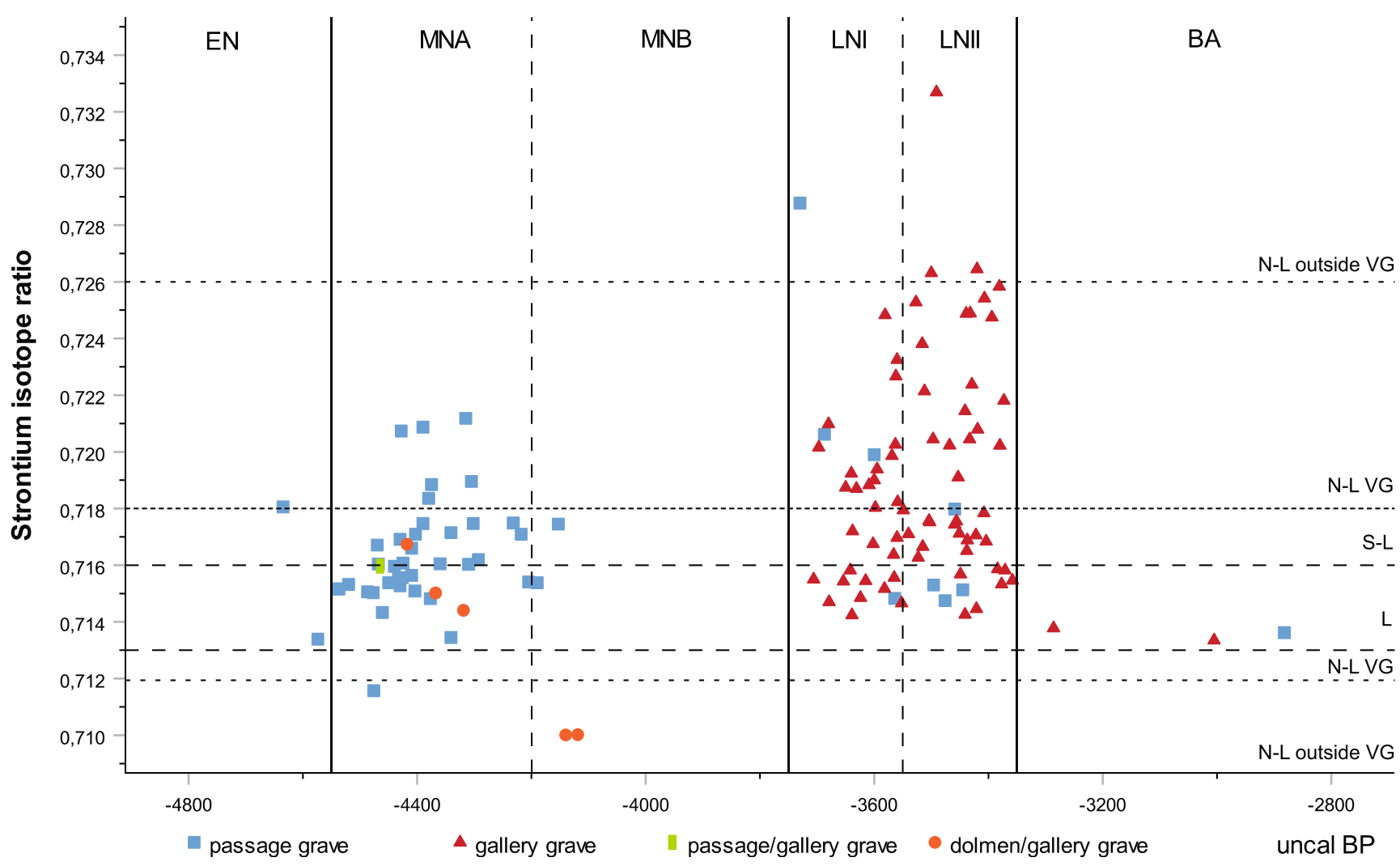

Fig. 9 Strontium isotope ratios of all ${ }^{14} \mathrm{C}$ dated individuals plotted by radiocarbon date and grouped by grave type. L, local to Falbygden; S-L, semilocal; N-L VG, non-local to Falbygden found within Västergötland; N-L outside VG, non-local range to Falbygden found outside of Västergötland 
ENII, MN

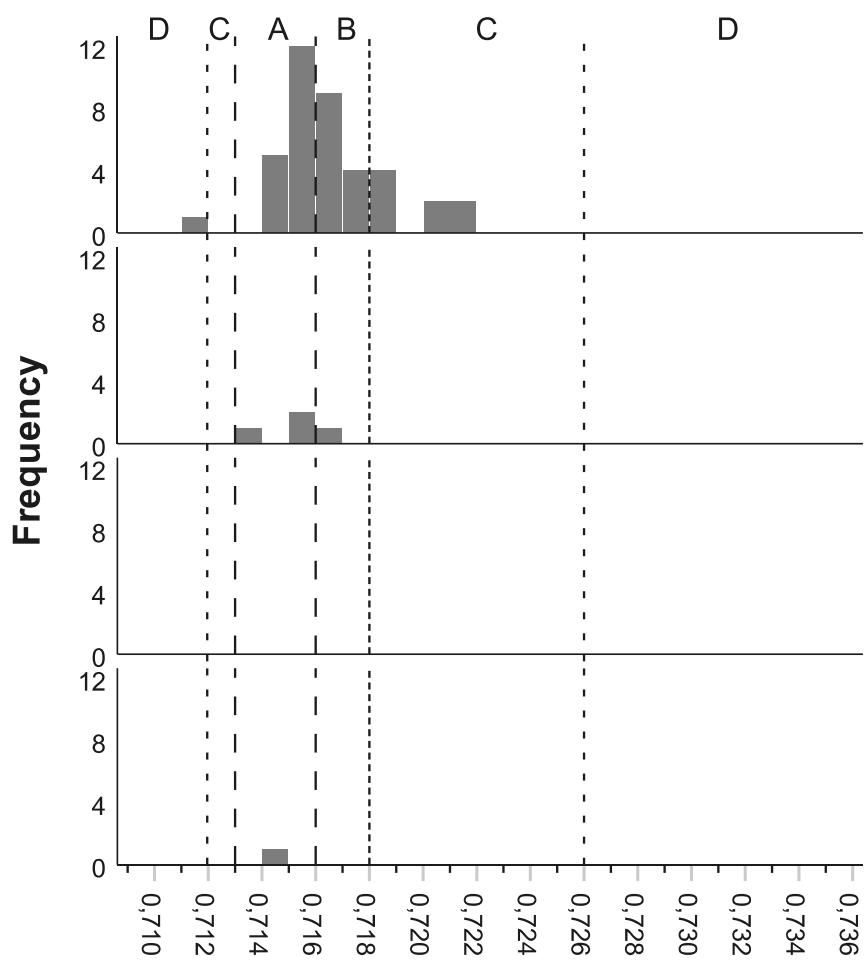

LN, EBA

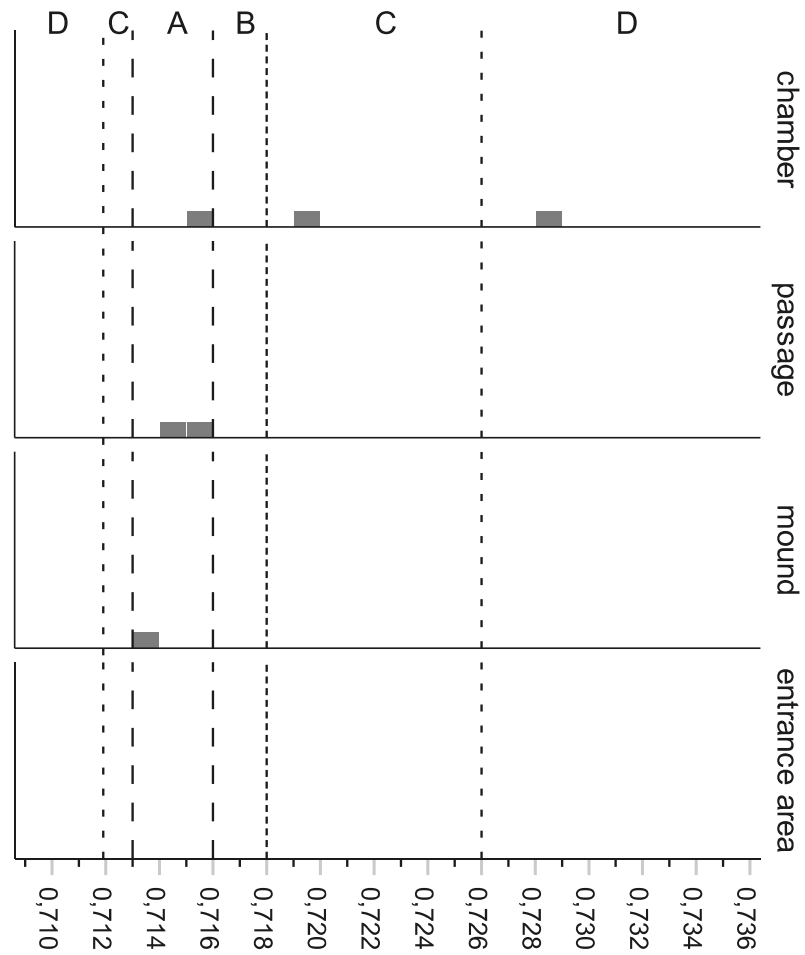

\section{Strontium isotope ratio}

Fig. 10 Histogram of Sr isotope ratios from individuals grouped by find location in passage graves. A Falbygden local range, $\mathbf{B}$ semi-local range, $\mathbf{C}$ nonlocal range to Falbygden found within Västergötland, D non-local range to Falbygden found outside of Västergötland

The results indicate a tendency for individuals in the peripheral parts of the grave to be local, assuming that the chamber is the primary place for deposition of dead bodies. Thus, it seems like locals occurred both in the inner and outer parts of the constructions, while the non-locals were mainly interred in the chambers. However, the human remains found in the entrances and passages might have been deposited in the chamber in a primary stage of the mortuary process. The difference in $\mathrm{Sr}$ isotope ratios between individuals deposited in the passage and the chamber is statistically significant (Mann-Whitney $U, p=$ 0.016 ). However, the low number of samples from other contexts than the chamber makes this suggestion only tentative. Furthermore, there is a tendency for covariation between $\mathrm{Sr}$ isotopes and location within the passage grave chamber at Valtorp 2. In this grave, significant differences in $\mathrm{Sr}$ isotope ratios (Mann-Whitney $U, p=0.008$ ) can be observed in the Middle Neolithic A between the two niches (Be 1 and 11), where most of the sampled individuals were buried (Fig. A2:3 and A3:1).The gallery graves show a similar pattern, but the differences are less certain due to the low number of samples outside the main chambers (Fig. A3:2).

In addition, we compared the $\mathrm{Sr}$ isotope ratios from individuals buried in graves with and without port-holes (Fig. 11). In southwestern Sweden, gallery graves with port-holes are common (see archaeological background). The emergence and spread of these graves have been extensively discussed (Blank et al. 2020; Ebbesen 2007:62; Janson 1938: 330ff; Kaelas 1967; Montelius 1905) and is still not resolved.

Most of the individuals buried in gallery graves with portholes are dated to the later part of Late Neolithic-Early Bronze Age, while the earlier phase is dominated by burials in graves without port-holes (Fig. 11), which agrees with the estimated chronology of the two grave types (Blank et al. 2020). Figure 11 shows that no Late Neolithic individuals with $\mathrm{Sr}$ isotope ratios over 0.721 occur in the gallery graves with portholes, whereas burials with ${ }^{87} \mathrm{Sr} /{ }^{86} \mathrm{Sr}$ ratios of up to 0.733 form a remarkable portion of the inhumations in gallery graves without a port-hole. During the Late Neolithic/Early Bronze Age, depositions of individuals with ratios between 0.719 and 0.723 were common in graves with port-holes, while such ratios were absent among the burials in the graves without port-holes. In these, the non-local ${ }^{87} \mathrm{Sr} /{ }^{86} \mathrm{Sr}$ ratios span from 0.724 to 0.727 . In both periods, the frequency of nonlocals is higher in the graves without port-holes and non-locals outside VG only appear in the graves without port-holes. The difference in $\mathrm{Sr}$ isotope ratios in teeth recovered from graves with and without port-holes is significant in the Late Neolithic, indicating a preference of burying individuals with non-local ratios in gallery graves without port-holes (Table A3:1). 
LN

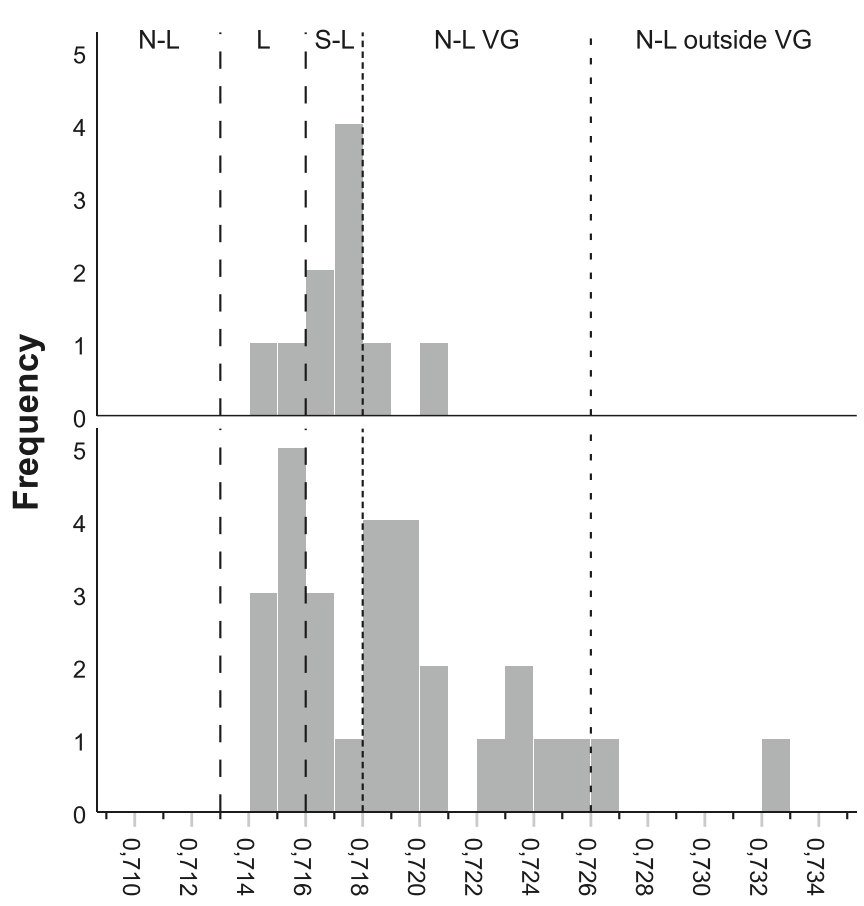

LN/EBA

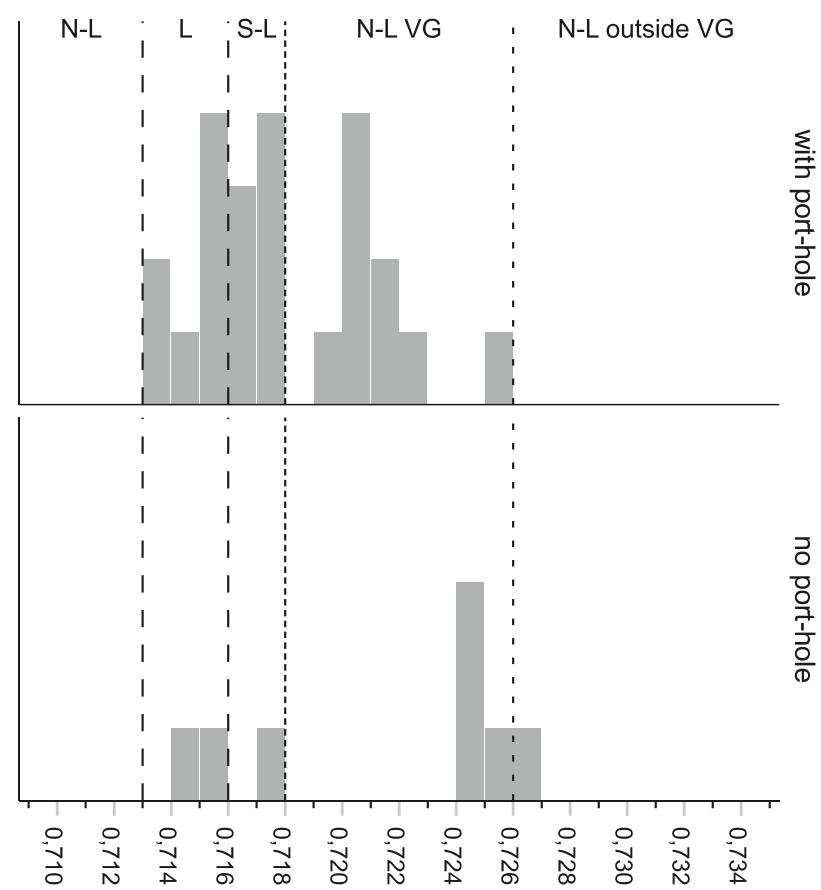

\section{Strontium isotope ratio}

Fig. 11 Histogram of $\mathrm{Sr}$ isotope ratios from individuals recovered in gallery graves with and without port-holes over time. L, Falbygden local range; S-L, semi-loca 1 range; N-L, non-local range to Falbygden;
N-L VG, non-local range to Falbygden found within Västergötland; N-L outside VG, non-local range to Falbygden found outside of Västergötland
ENII, MN

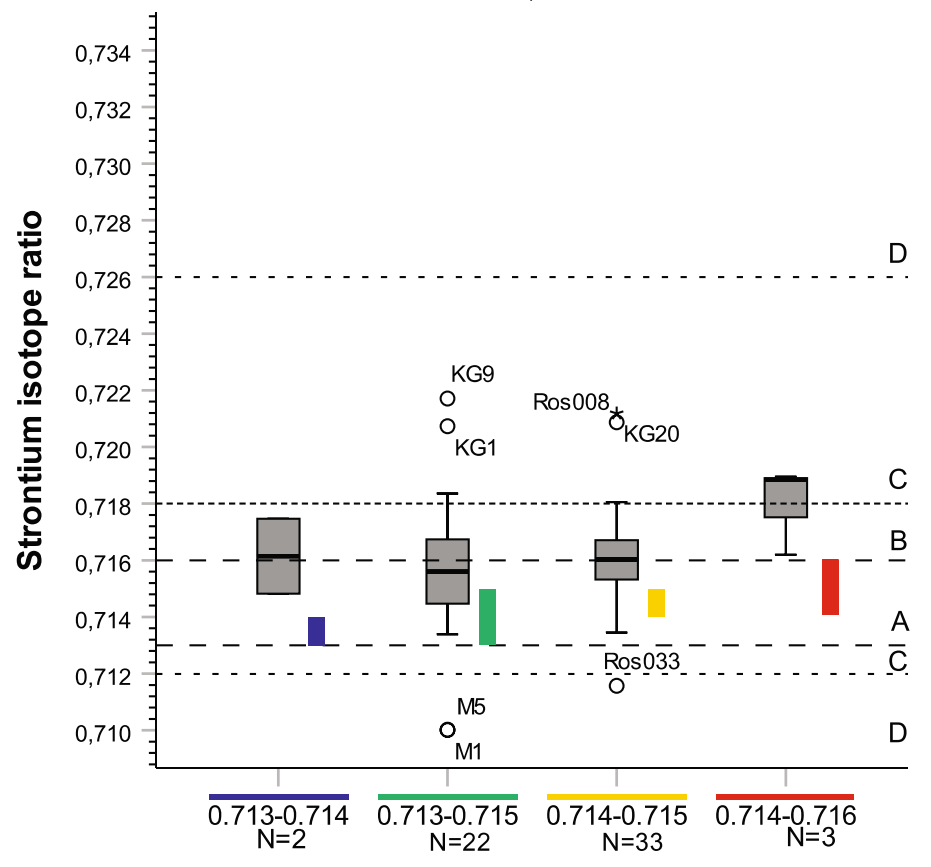

Site local range

Fig. 12 Boxplot of $\mathrm{Sr}$ isotope ratios grouped by site local bioavailable isotope ranges. Line: median, box: $25-75$ th percentile, whisker: ca $95 \%$ of the data and circles: outliers. Data in Table A3:2. A Falbygden local
LN, EBA

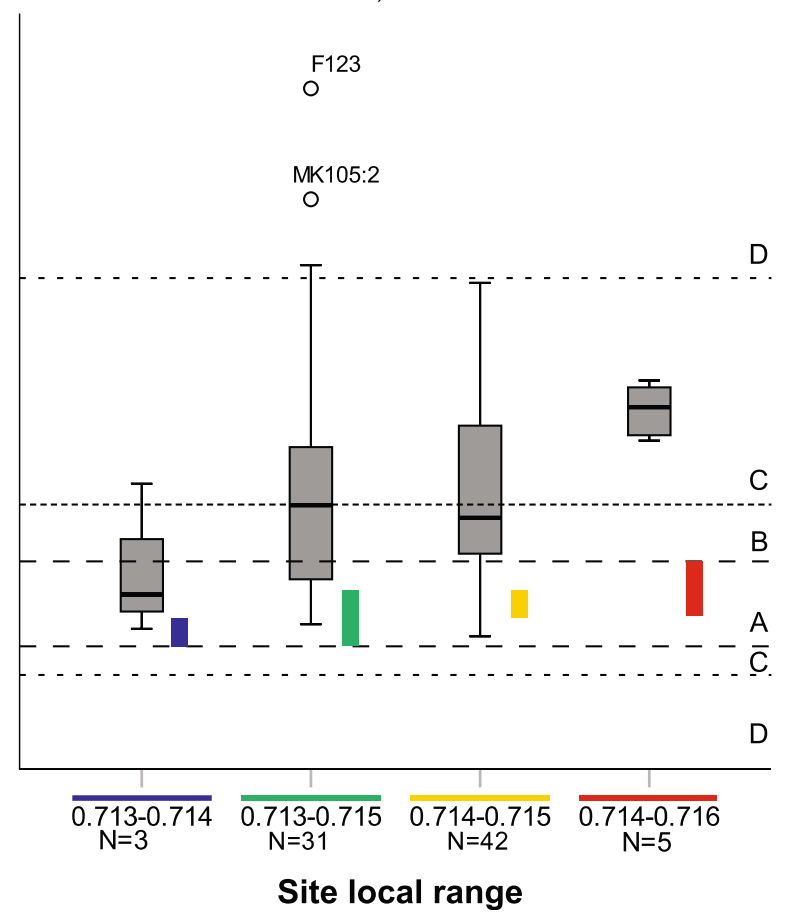

range, $\mathbf{B}$ semi-local range, $\mathbf{C}$ non-local range to Falbygden found within Västergötland, D non-local range to Falbygden found outside of Västergötland 


\section{Strontium isotopes, geology and location}

The baseline study (Blank et al. 2018a) concluded that the isotope ratios of the bioavailable $\mathrm{Sr}$ within Falbygden were independent of the different lithologies, while geography seemed more relevant, due to glacial mixing and movement of sediments. Nevertheless, data distributions are evaluated according to the geological conditions at the respective sites (Fig. A3:3), which supported the above finding. To investigate the geographical aspect of the sites, we compared the results from the individuals with the bioavailable $\mathrm{Sr}$ isotope ranges within $1-\mathrm{km}$ radius of the graves where they were found (Fig. 12). The homogenous baseline data limit the study of movements, as most of the sites fall within the same $\mathrm{Sr}$ isotope intervals. Nevertheless, this approach might give us some clues to mobility patterns within Falbygden.

Figure 12 demonstrates that most of the human data are higher than what is found in the immediate surroundings of the sites. A tendency for higher $\mathrm{Sr}$ isotope ratios among the buried individuals in areas with higher site local ranges can be discerned. However, the two groups with highest site local ranges only include eight individuals, while the group $0.714-0.715$ comprises 75 individuals.

The proportion of humans with a site local ratio is low in both periods (11.7\% in Early Neolithic-Middle Neolithic and $11.1 \%$ in Late Neolithic-Early Bronze Age, Table A3:2). Assuming that agricultural fields and water sources providing most of the biologically available Sr instead were located in a radius of $5 \mathrm{~km}$ around the burial site (1-h walking distance), the proportion of individuals within these ranges are considerably higher in the Early Neolithic-Middle Neolithic (32\%), while it remains low in the Late Neolithic-Early Bronze Age (17\%, Table A3:3 and A3:4). Tentative explanations are developed in the discussion section.

In Supplementary Material 2, plots of the Sr isotope results from each site are presented, and in Supplementary Material 3 (Fig. A3:4), Sr isotope ratios are plotted in smaller geographical areas within Falbygden, which enable more detailed comparisons of variations in mobility patterns.

\section{Sex assessment}

Fifty two of the individuals could be assigned to morphological sex (Table 4). Of these, 27 were females and 25 males. In addition, biological sex based on the ratio of $\mathrm{X}$ and $\mathrm{Y}$ chromosome and on the ratio of $\mathrm{X}$ and automsomal sequence data could be assigned to 64 individuals (including the six previously published samples). Of these, 33 are females, 21 males, 3 girls and 7 boys (Table 4). Overlapping morphology and genetic data were available for 19 individuals, and in 16 of the cases, morphological and biological sex estimations agreed, while in three cases they differed (Supplementary Material 1). In our study, we used the biological sex, and when missing, we included the morphological sex assessment.

Individuals published in Skoglund et al. 2014 and in Malmström et al. 2019

Overall, an even distribution of sex among the sampled individuals occurs (Table 4). In the Early Neolithic-Middle Neolithic phase, 39 individuals were assigned to sex: 19 females, 15 males, 1 girl and 4 boys. In the Late Neolithic-Early Bronze Age, sex estimations of 58 individuals are available: 27 females, 2 girls, 26 males and 3 boys (Supplementary Material 1). In most sites with several sampled individuals, the proportions of males and females seem relatively equal, with the exception of Torbjörntorp 18 gallery grave. Here, 12 of 16 individuals were assigned to female sex (including one girl). However, Lennblad (2015) suggested an even distribution of morphological sex in the total human remains of the grave. Furthermore, four of five sampled Middle Neolithic children buried in Valtorp 2 passage grave were boys as well as all sampled children in the Late Neolithic Torbjörntorp 31 gallery grave (Supplementary Material 1).

\section{Strontium isotope ratios, sex and age of death}

Males and females in the two main periods of use exhibit similar proportions of local, semi-local and non-local ratios (Fig. 13). There is no statistically significant difference in $\mathrm{Sr}$ isotope ratios between sexes in general (Mann-Whitney $U$ test, $p=0.377$ ) or in the two main phases of use (MannWhitney $U$ test, Early Neolithic-Middle Neolithic $p=0.825$, Late Neolithic-Bronze Age $p=0.524$ ). However, although few, during both phases, the persons with the highest $\mathrm{Sr}$ ratios were females. Furthermore, ratios between 0.720 and 0.722 are mostly found among females (Fig. 13).

In the last part of Late Neolithic, clusters of males $\left({ }^{87} \mathrm{Sr} /{ }^{86} \mathrm{Sr}=0.724-0.727\right)$ and females $(0.720-0.722)$ occur. The main part of the sampled teeth in these clusters reflects the first years of childhood. Thus, the Sr isotope ratios most probably mirror the origin of people moving in to Falbygden in
Table 4 Sex assessment of individuals included in the study

\begin{tabular}{llllll}
\hline & Female $(N)$ & Male $(N)$ & Unassigned $(N)$ & Girls $(N)$ & Boys $(N)$ \\
\hline Morphological sex & 27 & 25 & 92 & - & - \\
Biological sex & $29+4^{*}$ & $19+2^{*}$ & 33 & 3 & 7 \\
Sex (morphological + biological) & $42+4^{*}$ & $39+2^{*}$ & 49 & 3 & 7 \\
\hline
\end{tabular}




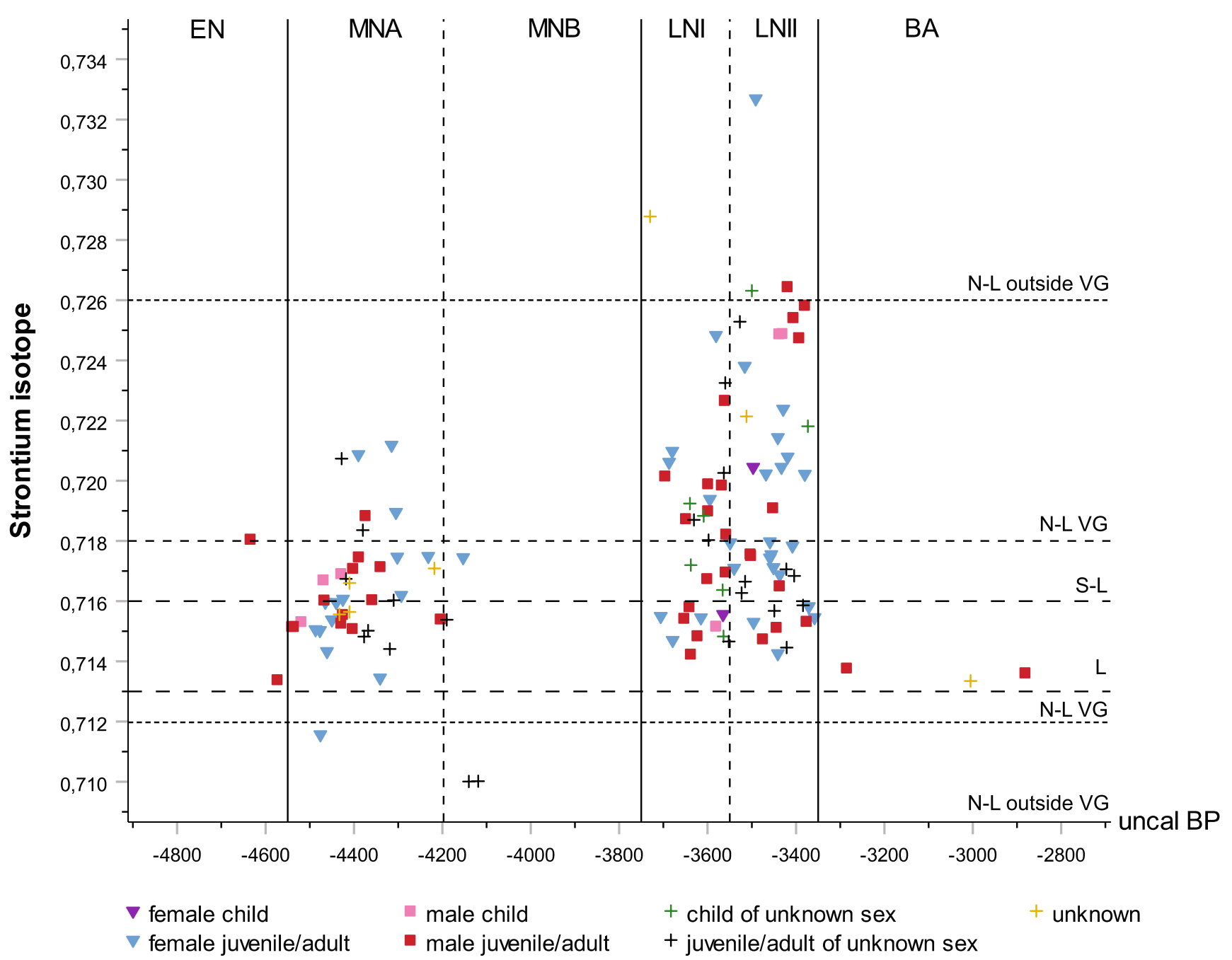

Fig. 13 Scatter plot of $\mathrm{Sr}$ isotope ratios of buried individuals over time grouped by biological sex and age. Female child $(N=2)$, female juvenile/ adult $(N=43)$, male child $(N=7)$, male juvenile/adult $(N=38)$, child of unknown sex $(N=6)$, juvenile/adult of unknown sex $(N=27)$, unknown sex and age $(N=16)$. L, Falbygden local range; $\mathrm{S}-\mathrm{L}$, semi-local range; $\mathrm{N}$ L VG, non-local range to Falbygden found within Västergötland; N-L outside VG, non-local range to Falbygden found outside of Västergötland

In the Early Neolithic-Middle Neolithic, only local and semi-local ratios occur among children and juveniles, while non-local ratios appear among the young adults and adults. In the Late Neolithic-Early Bronze Age, individuals exhibiting non-local ratios are common among both children and adults, while only one of the juveniles displays a local ratio (Fig. 14). Thus, we discern a different mobility pattern of the age groups between the two main phases of megalithic use.

Figure 14 also demonstrates that a greater number of female than male adults occur within the semi-local range during the Late Neolithic and Early Bronze Age, while in the Early and Middle Neolithic, the semi-locals are evenly distributed between sexes. The overrepresentation of females in the semi-local range is due to a cluster of females with ratios between 0.717 and 0.718 . In the Early Neolithic-Middle Neolithic, more male than female adults exhibit local ratios, while this group is evenly distributed between sexes in the 
ENII, MN

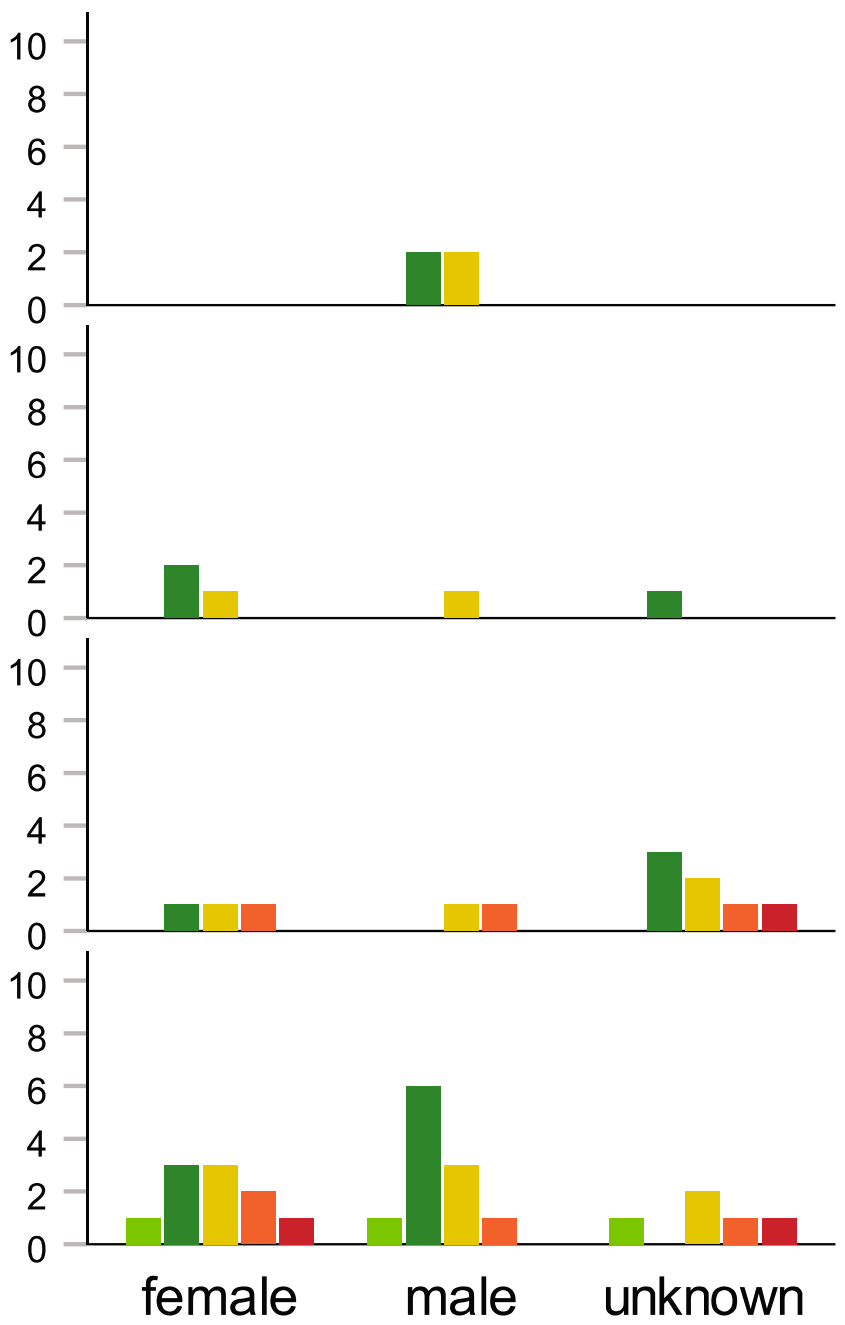

LN, EBA

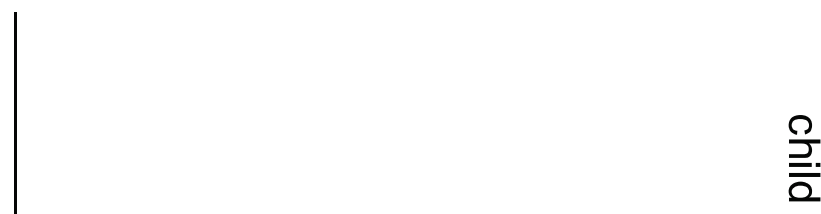

$\frac{\rho}{2}$
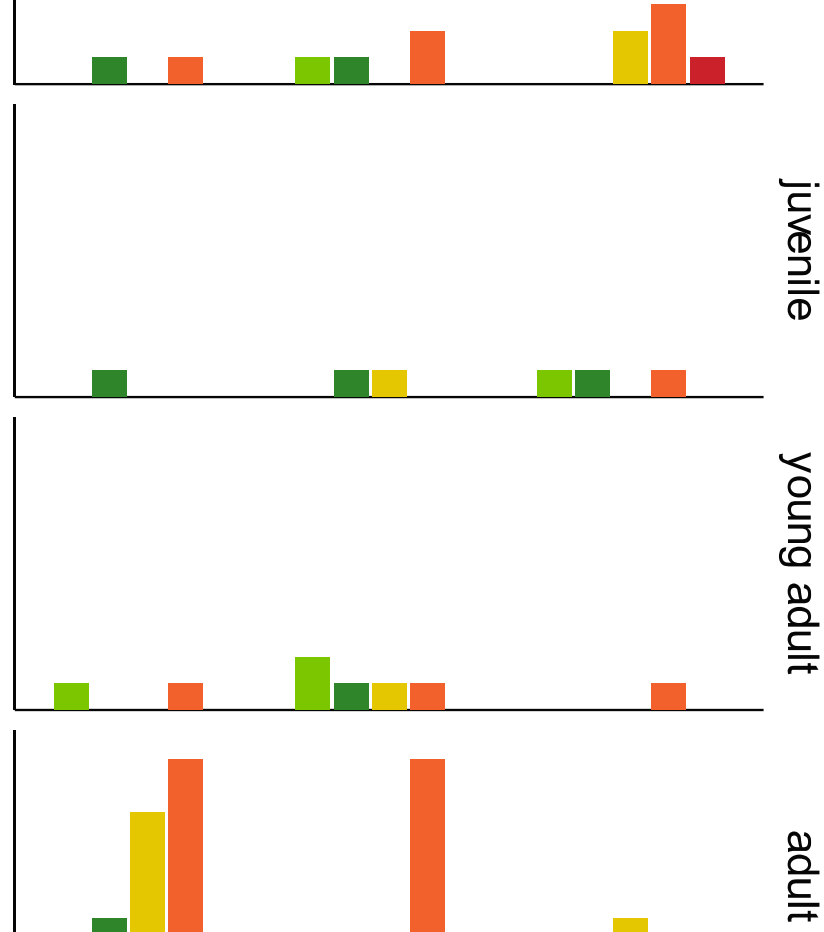

를
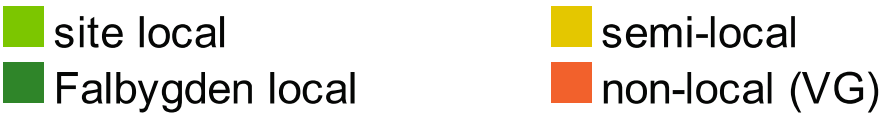

female male unknown

Fig. 14 Histogram of number of individuals grouped by Sr isotope ratios within various ranges, age groups and by biological sex, in the two main phases of use. Orange and red represent individuals with ratios not found in Falbygden. VG, Västergötland

later phase (Fig. 14 and A3:6). Thus, considering the Sr isotope categories rather than the $\mathrm{Sr}$ isotope ratios, the mobility pattern of adult males and females seems to differ between the Early Neolithic-Middle Neolithic and the Late Neolithic-Early Bronze Age.

\section{Multi-sampled individuals}

Teeth with enamel formed at different ages can give us more detailed information about individual movements. In 17 cases from three closely located gallery graves (Torbjörntorp 16, 18, and 31) and one gallery/ passage grave (Blinningsberg), several teeth from the same individual were analysed for their $\mathrm{Sr}$ isotope composition. The two molars from a Middle Neolithic male juvenile buried in the Blinningsberg grave both exhibited ratios within the local range of Falbygden and is further discussed in Supplementary Material 2.

In the three Late Neolithic gallery graves in Torbjörntorp parish, $\mathrm{Sr}$ isotope ratios of enamel that formed in different phases of childhood gave evidence of very different individual mobility patterns. The data indicate residential changes already during childhood into and out of Falbygden as well as movements within and outside of Falbygden. Other individuals had similar strontium isotope ratios throughout their childhood, which either matched the values typical of Falbygden or differed from them. The first are supposedly 
Torbjörntorp 16

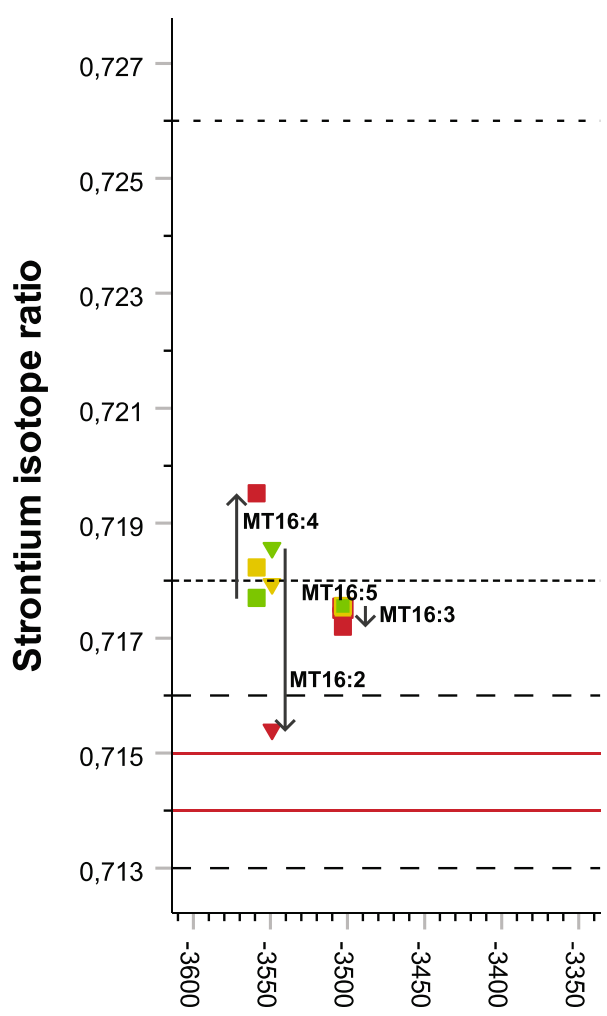

Torbjörntorp 18

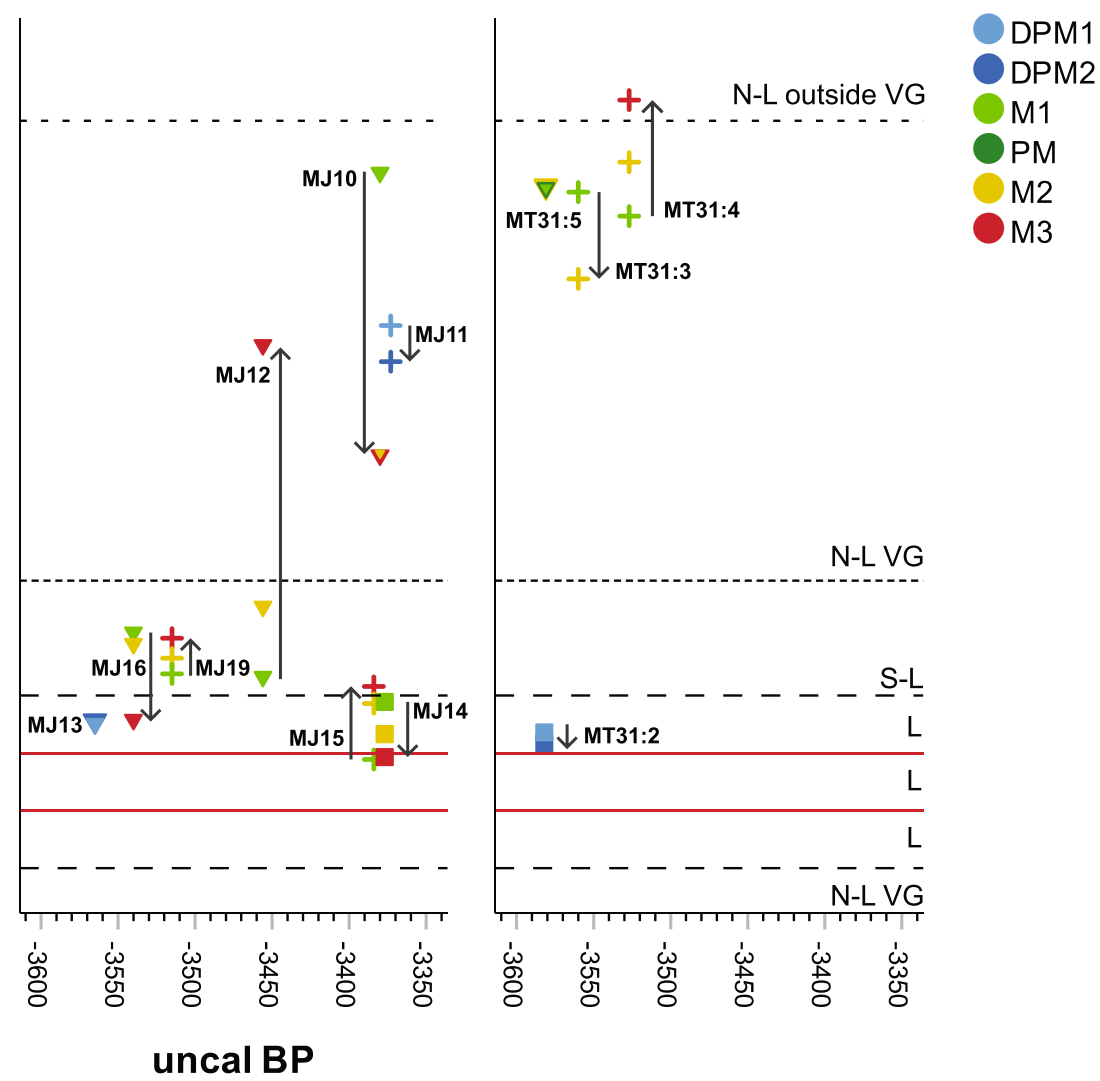

Fig. 15 Scatterplot of Sr isotope ratios from different stages of childhood/ youth of LN individuals buried in three gallery graves in Torbjörntorp parish. Squares, male; triangles, female; crosses, unknown sex. DPM, deciduous premolar; M, molar; PM, premolar. L, Falbygden local range; S-L, semi-local range; N-L VG, non-local range to Falbygden found within Västergötland; N-L outside VG, non-local range to Falbygden found outside of Västergötland. Red lines indicate the site local range, while the local range refers to the entire range within Falbygden local individuals, whereas the latter pattern indicates movement into the area during adulthood when enamel formation was complete (Fig. 15).

According to these data, specific mobility patterns do not seem to be linked to biological sex or to age of death (Fig. 15 and A3:7). A possible exception regards the youngest children. Two of the three children, MJ13 and MT31:2, exhibit very similar ratios in their two deciduous molars, which might indicate that women in their late pregnancy and children younger than 10 months were mostly stationary. After the age of three, movements appear which can be observed by different ratios between M1 and M2. Ratios differing between the M2 and M3, seen in some individuals, indicate mobility between c. 8 and 16 years.

In the Torbjörntorp 16 gallery grave, a 40-50-year-old female, MT16:2, seems to have moved in to Falbygden in late childhood/early teens, tentatively from the more radiogenic surroundings of Falbygden (Fig. 2 and 15). A similar pattern can be observed for a 35-50-year-old female MJ16 buried in Torbjörntorp 18. However, the first two molars display semilocal ratios, which might originate from a location in the outskirts of Falbygden or another place with a similar Sr isotope ratio. It might likewise be a mix of ratios from Precambrian and Cambrosilurian areas. A mixed ratio could result from imported foods, regular movements in and out of the area, or a single movement in or out from Falbygden at the time of enamel formation. The two first alternatives are more likely as both M1 and M2 exhibit similar ratios.

Movements outside of Falbygden were detected in all three graves among one male (MT16:4), two females (MJ10, MJ12) and three individuals of unknown sex (MJ19, MT31:3, MT31:4). It is unlikely that these individuals spent their childhood in Falbygden, although the above-mentioned alternatives must be taken into consideration for some of them. In the male MT16:4 and the female MJ12, the ratios go from semi-local to non-local. MJ12 might be a returning individual spending her M3-formation age elsewhere, although the lower $\mathrm{Sr}$ isotope ratio in the $\mathrm{M} 1$ rather reflects an origin in the outskirts of Falbygden or in another sedimentary area with similar ratios. Two further individuals, the female MT31:5 and the child MJ11, display relatively homogeneous non-local ratios in the different teeth (Fig. 15 and A3:7). Thus, all of these 
individuals except for the 4-5-year-old M11 probably moved to Falbygden in their adult lives or were brought to Falbygden only to be buried.

Another two children, a girl (MJ13) and a boy (MT31:2), exhibit ratios local to Falbygden, indicating that the mothers lived somewhere in this area while pregnant. In two adults, MJ14 and MJ15, variations in the Sr isotope ratios indicate possible movements within the Falbygden area. In the case of MJ14, a male, it seems like he moved closer to the burial site in his late childhood, while MJ15 moved away from the site during childhood (Fig. 15 and A3:7).

Type or timing of movements was in these cases independent of sex. Considering all sampled individuals in these graves, there are large differences in the Sr isotope ratios of non-locals. For example, in Torbjörntorp 16, all non-local Sr isotope ratios are lower than 0.720 , while in Torbjörntorp, they are higher than 0.723 . The difference in the non-local ratios between the graves is statistically significant (TB 16 and TB 31: $p=0.003$, TB16 and TB18: $p=0.011$, and TB18 and TB31: $p=0.013$ ). More details about the individual samples and the variations between the sites are discussed in Supplementary Material 2.

\section{Mitochondrial DNA haplogroups and strontium isotope ratios}

In general, the samples displayed the properties expected for ancient DNA data. We excluded a few samples with extreme average read lengths or with extreme mitochondrial contamination estimates (above 15\%) (Supplementary Material 1). Remaining samples had average read length ranging from 50 to 101 base pairs, and ratios of $\mathrm{C}$ to $\mathrm{T}$ and $\mathrm{G}$ to $\mathrm{A}$ damages at the ends of the reads ranging from 0.09 to 0.51 .

Mitochondrial DNA haplogroups are determined for 40 individuals from nine different graves (Table 2). Additionally, we included four individuals from the Middle Neolithic passage grave Gökhem 94 with previously determined mtDNA haplogroups (Skoglund et al. 2012, 2014; Supplementary Material 2) and haplogroups from two Middle Neolithic individuals buried in Valtorp 2 passage grave (Malmström et al. 2019). Presented below in Table 5 is the distribution of simplified mtDNA haplogroups between the two main phases of megalithic graves. The most common mtDNA haplogroups in our samples during the Early Neolithic-Middle Neolithic are $\mathrm{H}$ and $\mathrm{K} 1 \mathrm{e}$ and in the Late Neolithic-Early Bronze Age are U5b and $\mathrm{T} 2 \mathrm{~b}$ (Table 5).

A replacement of haplogroups occurs with the disappearance of some and the appearance of other groups over time. The X2b, K1b and K1e haplogroups are only present among Middle Neolithic individuals, while the HV0, T, U4a, U4c and I4a haplogroups only are identified among Late Neolithic and Late Neolithic/Early Bronze Age individuals (Table 5). Furthermore, the T, U4a, U4c and I4a only occur
Table 5 Number of individuals assigned to different mtDNA haplogroups in the two main phases

\begin{tabular}{lll}
\hline Simplified mtDNA haplogroup & $\begin{array}{l}\text { ENII, MN } \\
(N)\end{array}$ & $\begin{array}{l}\text { LN, EBA } \\
(N)\end{array}$ \\
\hline K1e & 5 & 0 \\
X2b & 3 & 0 \\
K1b & 1 & 0 \\
H & 6 & 2 \\
U5b & 3 & 5 \\
K1a & 1 & 2 \\
J1c & 1 & 2 \\
U5a & 1 & 2 \\
T2b & 1 & 5 \\
T & 0 & 1 \\
HV0 & 0 & 1 \\
I4a & 0 & 1 \\
U4c & 0 & 1 \\
U4a & 0 & 2 \\
\hline
\end{tabular}

in the latest part of the second phase, suggesting an introduction of several new haplogroups in the Late Neolithic II and transition to Early Bronze Age (Fig. A3:8). A continuation of the mtDNA haplogroups H, U5b, K1a, J1c, U5a, and T2b was also observed (Table 5).

Considering the sex assessments of the individuals, there seems to be a greater variation of haplogroups among the females dated to the Late Neolithic-Early Bronze Age (Fig. A3:9). Furthermore, all but one of the new haplogroups appearing in the Late Neolithic-Early Bronze Age were found exclusively among females. However, these groups are only represented by few or single individuals (Fig. A3:9).

There seems to be a greater variation of mtDNA haplogroups in the Late Neolithic and Early Bronze Age (11 groups) than in the earlier periods (9 groups, Table 5). To ensure that the uneven number of sampled individuals did not bias this, we calculated richness and evenness measures for the two main phases. The Late Neolithic-Early Bronze Age period demonstrates a slightly greater richness of haplogroups (Table 6). Furthermore, the results demonstrate that the haplogroups were more evenly distributed during the Late Neolithic-Early Bronze Age than in the Early NeolithicMiddle Neolithic phase (Table 6).

Menhinick's richness index equals the ratio of the number of taxa to the square root of sample size. The higher the index $\mathrm{D}$, the higher the richness. Shannon H index accounts for the number of individuals as well as number of taxa. It varies from 0 with only a single taxon present to high values for many taxa, each with few individuals. The higher the index $\mathrm{H}$, the higher the evenness between the groups 
Table 6 Diversity measures of simplified mtDNA haplogroups in the two main phases

\begin{tabular}{lll}
\hline & EN-MN & LN-EBA \\
\hline Richness/Menhinick D index & 2.012 & 2.245 \\
Evenness/Shannon H index & 1.987 & 2.219 \\
\hline
\end{tabular}

Interestingly, the apparent greater variation in mtDNA haplogroups in Late Neolithic and Early Bronze Age is concordant with the greater variation of $\mathrm{Sr}$ ratios and the strong increase of non-locals compared to the Middle Neolithic period. It can be noted that U5b only occurs in a Falbygden local cluster $(0.715-0.716)$ in the Early Neolithic/Middle Neolithic, while it only appears in a non-local cluster $(0.724-0.726)$ in the Late Neolithic/Early Bronze Age (Fig. 16). However, these are not necessarily the same variants of the U5b haplogroup. The individuals with non-local $\mathrm{Sr}$ isotope ratios were assigned to mtDNA haplogroups K1a (low ratios) and $\mathrm{H}$ (high ratios). Furthermore, the T2b haplogroups have a wider Sr isotope range than the other groups in the Late Neolithic-Early Bronze Age (Fig. 16). Other than that, no correlation can be discerned between mtDNA haplogroups and the $\mathrm{Sr}$ isotope ranges.

To some extent, haplogroups also vary between graves as some groups are only represented in certain graves. Within several sites, individuals share haplogroups indicating a possible maternal affinity (Supplementary Material 2). For example, the $\mathrm{X} 2 \mathrm{~b}+226$ group only occurs in the Valtorp 2 passage grave among two boys and a male adult with overlapping radiocarbon dates suggesting a common origin or kin relation. However, matching mtDNA haplogroups do not necessarily denote close genetic affinity. In the Late Neolithic-Early Bronze Age, the only grave with individuals assigned to the U5b haplogroup is the Torbjörntorp 31 gallery grave, while U4 groups only appear in the close by Torbjörntorp 18 (Supplementary Material 2). Furthermore, the richness and evenness of mtDNA haplogroups differ between the two closely located Late Neolithic-Early Bronze Age gallery graves (Table A3:5). However, the richness might be related to the duration of the use of graves, as the grave with the greatest richness in this case was used for a longer time than the other.

In Torbjörntorp 31, five of the individuals with non-local Sr ratios between 0.723 and 0.727 could be assigned to the U5b mtDNA haplogroup (Supplementary Material 2; Fig. A3:8). Four of them were males with similar radiocarbon dates (the late Late Neolithic II), and the fifth was a female with a slightly earlier date (Fig. A2:9).

In Valtorp 2, two of the three males with the X2b+226 haplogroup had similar semi-local $\mathrm{Sr}$ isotope ratios and radiocarbon dates, and they were found in the same niche of the grave chamber. In addition, individuals in Valtorp 2 assigned

\section{ENII, MN}

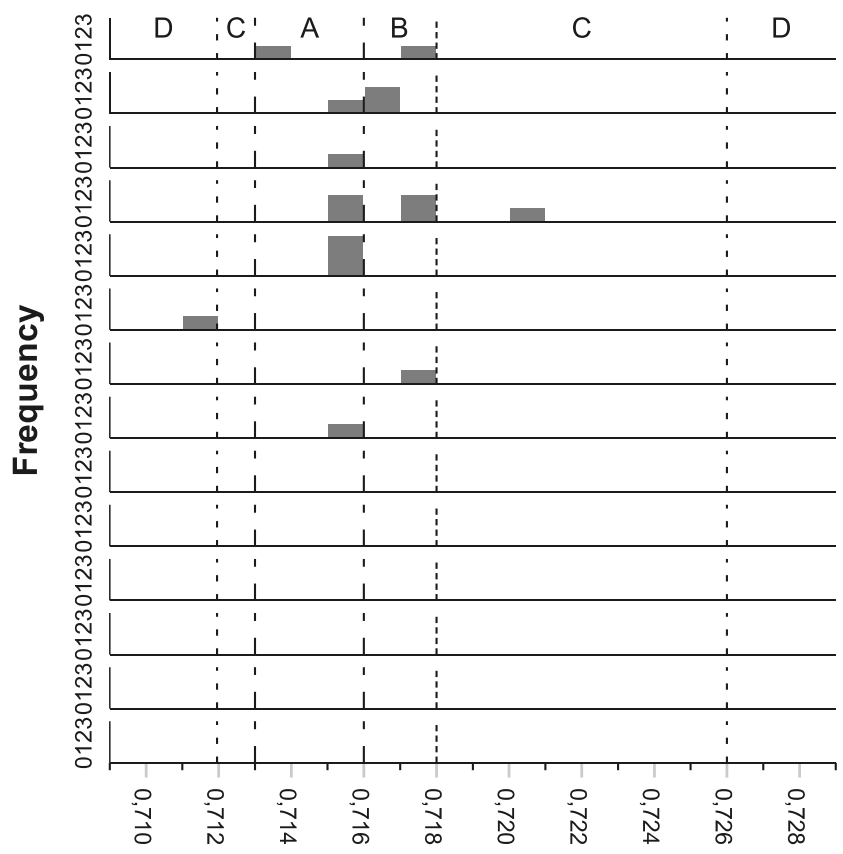

LN, EBA

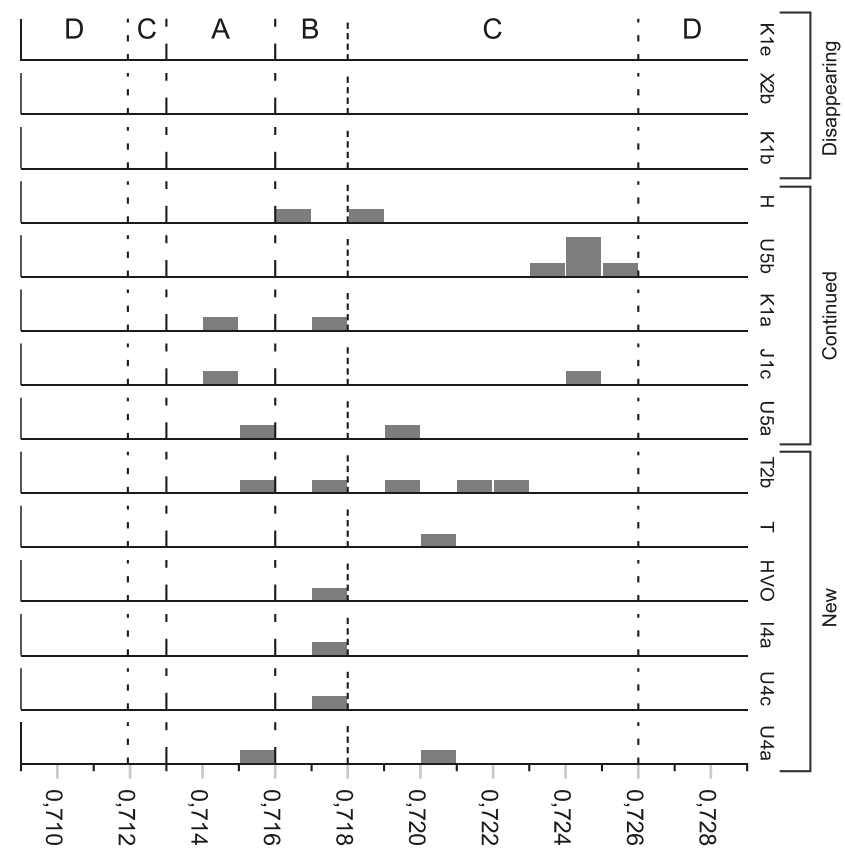

\section{Strontium isotope ratio}

Fig. 16 Histogram of Sr isotope ratios grouped by simplified mtDNA haplogroups in the two main phases of use. A Falbygden local range, B semi-local range, $\mathbf{C}$ non-local range to Falbygden found within Västergötland, D non-local range to Falbygden found outside of Västergötland 
to haplogroup U5b3 (three) and U5a2 (one) display similar Falbygden local $\mathrm{Sr}$ isotope ratios and only appear in niche $\mathrm{Be} 11$. The individuals assigned to U5b3 had similar early Middle Neolithic A dates, while the female exhibiting an U5a2 haplogroup had a slightly later date (Fig. A2:3). Thus, in the case of Valtorp 2, it seems that different kinship groups may have used different niches of the chamber.

In addition, some individuals with overlapping radiocarbon dates from different graves displayed the same haplotypes. The haplogroups $\mathrm{K} 1 \mathrm{e}$ and $\mathrm{H} 24$ are assigned to individuals buried in the passage graves Valtorp 2 and Gökhem 94 (Supplementary Material 1 and 2). A Late Neolithic/Early Bronze Age child from Torbjörntorp 31 shares the same haplogroup, T2b+16362, with a Late Neolithic/Early Bronze Age female buried in Borgunda 106.

\section{Discussion}

\section{Population dynamics in the Neolithic and Early Bronze Age}

In this paper, we demonstrated an increased human mobility in the Late Neolithic-Early Bronze Age, supported by a distinct difference in $\mathrm{Sr}$ isotope ratio and mtDNA haplogroup variation compared to the Early-Middle Neolithic among the megalithic population of Falbygden. Furthermore, individuals with new mtDNA haplogroups and Sr isotope ratios previously not found in the area occur in the Late Neolithic. The frequency of non-local individuals as well as the variation of $\mathrm{Sr}$ isotope ratios and mtDNA haplogroups increases sharply in the Late Neolithic, peaking in the Late Neolithic II and the transition between the Late Neolithic and the Early Bronze Age.

The model of an increased human mobility in the Late Neolithic of Falbygden is further supported by a greater variation of childhood $\delta^{15} \mathrm{~N}$ values than in the Middle Neolithic, although this could partly be a result of changed subsistence strategies (Blank 2019; Blank et al. 2018b).

In this study, there are differences in mtDNA haplogroups between the two main periods of megalithic grave use, with a greater variation and partial replacement of haplogroups in the later phase. The Late Neolithic period was preceded by a migration of $\mathrm{CW}$ people moving into Scandinavia from continental Europe bringing in new genetic ancestry and mixing with existing TRB groups (Malmström et al. 2019). The differences seen in the mtDNA haplogroups in Late Neolithic probably already originate in the Middle Neolithic B with the establishment of BAC groups in the area, although the variation of haplogroups seems to increase further at the transition between Late Neolithic and Early Bronze Age.

Most of the mtDNA haplogroups found in this study are known from other Neolithic contexts in Scandinavia and northern Europe (Bergerbrant et al. 2017; Fraser et al. 2018a, b; Malmström et al. 2009, 2015, 2019; Skoglund et al. 2012, 2014). Varieties of U5 and U4 haplogroups are common in Scandinavia during the Mesolithic (e.g. Günther et al. 2018). However, the $U$ haplogroups present in, for example, the Middle Neolithic passage grave Valtorp 2 have formerly been linked to PWC individuals and have not previously been found in Middle Neolithic megalithic graves (Fraser et al. 2018a, 2018b; Malmström et al. 2009, 2010, 2015; Skoglund et al. 2012, 2014). The X2b and I4a haplogroups, the latter assigned to a young Late Neolithic female with a peri-mortem injury to the skull buried in the Middle Neolithic Luttra 16 passage grave, are less common and have previously not been observed in Scandinavia during these or earlier periods. I4a has previously been found in Bronze Age individuals from Great Britain, Germany, Czech Republic, Lithuania and Russia, and some of these were associated with CWC (Allentoft et al. 2015; Juras et al. 2018; Mittnik et al. 2018; Olalde et al. 2018). The X2b group assigned to two Middle Neolithic A males and a boy in Valtorp passage grave have in earlier studies been found in, e.g. Neolithic Great Britain, Copper Age Portugal and Spain, and in Early Bronze Age Germany (Knipper et al. 2017; Olalde et al. 2018).

If we compare the mobility pattern in Falbygden with other regions in south Scandinavia, parallels and dissimilarities can be observed. Sr isotope data also point to a shift in human mobility between the Danish Neolithic and Early Bronze Age. However, it seems to have taken place c. 200 years later than in Falbygden, i.e. in the Early Bronze Age, and was interpreted as related to the expansion of the early Nordic Bronze Age (Frei et al. 2019a). It should be mentioned that only 10 out of 88 Danish individuals dated to the Middle Neolithic.

In a study of Late Neolithic and Early Bronze Age burials in Scania, Sr isotope ratios indicate that the proportion of nonlocals peaked in the Late Neolithic II, 1950-1700 cal BC (Bergerbrant et al. 2017), although these results must be treated with caution as they include only few Late Neolithic individuals and as no detailed baseline has yet been established for Scania. On the island of Gotland, in the Baltic, an increased human mobility was also suggested in the Late Neolithic/ Early Bronze Age based on $\mathrm{Sr}$ isotope data (Fraser et al. 2018b). According to a study of sulphur isotopes (Linderholm et al. 2014), an increased number of non-local individuals occurred at the transition between Late Neolithic and Early Bronze Age. Thus, the Falbygden results seem to correlate with several other regions in Sweden, while the Danish material suggests an increased mobility later on, in the Early Bronze Age.

The increased human mobility observed in the Late Neolithic-Early Bronze Age could possibly be connected to a general population growth in middle and south Sweden, 
which previously has been proposed based on the spread of artefacts and gallery graves as well as increased farmland areas in southern Sweden (Apel 2001; Artursson 2009; Enevold 2019; Lekberg 2002; Weiler 1994). The exploitation of new locations and an augmented population pressure could have resulted in migrations and extended networks. Thus, the increased mobility in the Late Neolithic may be related to an expansion of exchange networks and to an increased population. In sum, these data indicate social transformation taking place in the onset of Late Neolithic II.

\section{Interpretations of strontium isotope ranges}

\section{Local ranges}

A local ratio implies that the individual probably resided in the area, or in a place with a similar range, and consumed local food and drink. As previously mentioned, the main sources for $\mathrm{Sr}$ in humans are plants and dairy products with some contribution from water. In Falbygden, the calcareous soils are favourable for agriculture and animal husbandry, and macrofossils and pollen analysis confirmed Neolithic cultivation and husbandry (Sjögren 2003; Sjögren et al. 2019). Furthermore, there are many natural springs, especially close to the megalithic graves and settlements (Schnell 1966; Sjögren 2003). Thus, local consumption can be assumed, even though the intake of some food from outside of this area cannot be ruled out.

Based on the current knowledge of the isotope ratios of bioavailable Sr within the sedimentary area of Falbygden, the local ${ }^{87} \mathrm{Sr} /{ }^{86} \mathrm{Sr}$ range has been estimated to between 0.713 and 0.716 . During the first phase of megalithic grave use, Early/Middle and Middle Neolithic, about $47 \%$ of the burials exhibit Falbygden local $\mathrm{Sr}$ isotope ratios. However, only about $12 \%$ of the data match the interpolated local ranges for a $1-\mathrm{km}$ radius of the specific grave site. In the second phase, the Late Neolithic and Early Bronze Age, only 38\% of the individuals display Falbygden local ratios, and $11 \%$ of them are local to the burial site. Thus, the proportion of site local ratios is similar, while the number of locals to Falbygden decreases in the Late Neolithic. The low number of individuals with site local ratios might result from high mobility within Falbygden and/or from use of much larger economic areas around the sites. Exogamous marriages along with other types of movements within Falbygden may explain the low number of site local individuals in the graves. However, the observation may also point to weaknesses in the baseline due to the complex geology or a lack of understanding of Sr uptake by humans. The (modern) water samples may not be completely representative for the bioavailable $\mathrm{Sr}$ of the soils on which the staple crops were grown. Springs come from underground aquifers may be more homogeneous/dominated by $\mathrm{Sr}$ from the calcareous fraction of the rocks, whereas $\mathrm{Sr}$ available from soils may come from more varied minerals and may be more variable. However, Blank et al. (2018a) demonstrated that the $\mathrm{Sr}$ isotope ratios of the small terrestrial mammals (prehistoric and modern) were in accordance with the water samples.

\section{Semi-local ranges}

The geographical distribution of gallery graves is greater than the distribution of Middle Neolithic megalithic graves. Furthermore, a general expansion of farming (e.g. Berglund 2003) and growing farmland areas within Falbygden (Enevold 2019) is proposed for the Late Neolithic period. A wider use of the landscape could lead to a greater variation of Sr isotope ratios, as would an increased consumption of non-local food. However, during this period, the variation of $\mathrm{Sr}$ isotope ratios only increases in the non-local range. Furthermore, the proportion of semi-local ratios, which might derive from the outskirts and the close surroundings of Falbygden, is low among the Late Neolithic burials.

Instead, the number of individuals with a semi-local ratio $(0.716-0.718)$ is greater during the Early Neolithic/Middle Neolithic than in the Late Neolithic/Early Bronze Age (35\% and $15 \%$ ). As previously proposed, the semi-local range could result from residing in locations found in the peripheries of the sedimentary area or south of Falbygden, but it could likewise represent a mixture of $\mathrm{Sr}$ from Falbygden and the surrounding Precambrian areas. As we worked with bulk samples that represent the whole preserved crown height, a mixed ratio could be obtained in a tooth if the person moved in to or out of Falbygden during the time of tooth formation. Another possible explanation is seasonal mobility that took place during the period of enamel mineralization and during which food sources were exploited on the way. Furthermore, a mixed ratio could be acquired if both local and imported food were consumed. The semi-local ratios measured in this study may therefore have several different explanations, which also may have varied over time.

Subsistence during both Middle Neolithic and Late Neolithic in Falbygden was mainly based on plant cultivation and animal husbandry of cattle, pigs, sheep and goats (Blank 2019; Sjögren 2017; Sjögren et al. 2019). A study of Middle Neolithic pottery from Falbygden found evidence of dairy products (Kaldhussæter Lindboe 2014). Ancient proteins from dental calculus of Middle Neolithic and Late Neolithic individuals from megalithic graves in Falbygden also point to the direct consumption of milk products (Fotakis et al. in preparation). In a mobility study of domestic animals in Middle Neolithic Falbygden (Sjögren and Price 2013a), the cattle displayed more varied and higher Sr isotope ratios than the humans. Seasonal movement of cattle could have affected the Sr isotope ratios of the herders if they went along as children. Seasonal dietary patterns, such as the consumption of 
leaf fodder or of grass, might also have resulted in variation of the Sr isotope ratios of animals, as the length of the plant roots differs significantly among species. Human diet based on different plant foods in different seasons is also possible. However, there are still factors concerning the Sr uptake in animals and humans that are not resolved.

The greater proportion of semi-local ratios in the Middle Neolithic than in the Late Neolithic might be associated to changed strategies for holding livestock. In one case (MJ19 from Torbjörntorp 18 gallery grave), three teeth display variations within the semi-local range, which may be explained as mixed ratios obtained by movements in and out of Falbygden during the time of teeth formation. Repeated movements in and out of Falbygden might have been connected to livestock management but also to movements between settlements belonging to networks in a larger region. In the Middle Neolithic, this implies mobility between megalithic and nonmegalithic areas. To evaluate the differences between the Early Neolithic-Middle Neolithic and the Late NeolithicEarly Bronze Age individuals with semi-local ratios, several teeth from more individuals and sequential sampling of teeth would be needed.

Nevertheless, in several Late Neolithic individuals where multiple teeth were sampled, the teeth exhibited very similar semi-local ratios, which are unlikely to result from mixing, although it cannot be excluded without micro-sampling. Similarities in $\mathrm{Sr}$ isotope ratios between different teeth are possible if, for example, a herder follows the same route year after year. It is likely that at least some of the semi-local ratios reflect actual locations of residence. Hence, the higher amount of semi-local ratios in the Middle Neolithic could indicate more intense migrations from locations in the peripheral parts and close to the sedimentary area, while the higher amount of non-locals in Late Neolithic and Early Bronze Age may reflect migrations from locations further away from Falbygden. This is further supported by the considerably higher proportion of individuals that fall within the $5-\mathrm{km} \mathrm{Sr}$ isotope range around the specific sites than the proportion within the 1-km site local range in the Early Neolithic-Middle Neolithic, compared to the insignificant difference that appears in the Late NeolithicEarly Bronze Age. Thus, the $\mathrm{Sr}$ isotope data supports increased movements in the landscape over larger areas during the Late Neolithic-Early Bronze Age, while the human mobility in the Early Neolithic-Middle Neolithic was restricted to a more limited geographical range.

\section{Non-local ranges}

Non-local ratios are much more common during the Late Neolithic-Early Bronze Age than in the Early NeolithicMiddle Neolithic, $47 \%$ versus $18 \%$ of the sampled individuals. Furthermore, the non-local ratios of the Early NeolithicMiddle Neolithic teeth do not measure higher ratios than
0.722, while Late Neolithic-Early Bronze Age individuals exhibit a higher variation including ratios up to 0.734 . One individual dated to Middle Neolithic A and two from Middle Neolithic B exhibited low non-local ratios between 0.712 and 0.710. Ratios from outside inland southwestern Sweden only represent a small part of the non-locals and appear in $5 \%$ of the individuals during the Early Neolithic-Middle Neolithic and Late Neolithic-Early Bronze Age. However, the ratios found in southwestern Sweden also occur in other regions further away.

The low non-local (outside VG) ratios found among Middle Neolithic individuals appear in southern Scania, at the Swedish west coast, and in Denmark. The high non-local (outside VG) ratios of the Late Neolithic-Early Bronze Age burials only occur east or northeast of Falbygden and in eastern Sweden. Radiogenic ratios representing eastern and northeastern regions also appear on Late Neolithic Gotland (Fraser 2018) and might reflect a general trend of more northern and eastern influences in southern Sweden during this time. Based on pottery decorations and temper, intensified connections between middle Sweden and more eastern regions, such as Finland, has been proposed already in the last part of Middle Neolithic (Larsson 2009). In sum, the results indicate an increased migration into Falbygden from new areas and human movements over larger areas in the Late Neolithic-Early Bronze Age.

\section{Strontium isotope ratios: age and sex}

During the Early Neolithic-Middle Neolithic phase, the lack of children and juveniles with non-local Sr isotope ratios suggest that most of the non-locals probably moved into Falbygden in a later stage of their life or were brought there as dead. In the Late Neolithic-Early Bronze Age, a relatively high proportion of non-locals occur among both children and adults.

In the Late Neolithic-Early Bronze Age, Sr isotope ratios of individuals with multiple sampled teeth indicate movements both into and out of Falbygden. Furthermore, movements during childhood were demonstrated. However, the Late Neolithic children with several sampled deciduous teeth indicate limited movements during the first year. Different molar teeth from other Late Neolithic individuals suggest mobility already from the age of about 3 years. Thus, the children were probably accompanied by adults and moved with groups/families, although practices such as fostering might also be an alternative. In addition, some of the movements traced in childhood and early youth may signify children engaged with herding or other activities that did not necessarily involve migration.

Even though mobility was observed in children, many of the multi-sampled Late Neolithic-Early Bronze Age individuals exhibited non-local or semi-local ratios in all teeth, 
suggesting that these people moved into Falbygden as adults or were brought there as dead. To investigate when or if the individuals with non-local ratios moved into Falbygden, more analyses of series of teeth from the same individual would be necessary. Furthermore, analyses of bones representing an age closer to death could be conducted, although the soil contamination must be considered.

Considering the $\mathrm{Sr}$ isotope categories, slight differences were observed in the adult population related to sex between the two phases. For example, the majority of the Early Neolithic-Middle Neolithic males (64\%) exhibited Falbygden local and site local ranges. In the Late Neolithic-Early Bronze Age, on the other hand, most of the males $(65 \%)$ displayed $\mathrm{Sr}$ isotope ratios that fell in the non-local ranges. This might be related to different types of mobility in the two phases. During the Early Neolithic-Middle Neolithic phase and in the first part of Late Neolithic, there is no significant difference in Sr isotope ratios between biological sexes, which could have been expected from exogamous marriages of matri- or patri-local character. However, in the Late Neolithic II-Early Bronze Age, the difference in non-local $\mathrm{Sr}$ isotope ratios between sexes was statistically significant. This suggests a change in mobility pattern in the Late Neolithic II, where females and males partly migrated from different areas or moved in different manners.

\section{The megalithic population of southwestern Sweden}

Males and females of all ages were buried in the megalithic graves, and the mix of ages and sex of the individuals is in line with a cross section of a population. It has been argued that these graves have been used for families and groups from nearby settlements (Ahlström 2009; Sjögren 2003; Weiler 1994). Based on aDNA studies, kin relations within megalithic graves, for example, in the Middle Neolithic Ansarve dolmen on Gotland, have been suggested (Sánchez-Quintoa et al. 2019).

Our results demonstrate that there are differences in the occurrence and frequencies of mtDNA haplogroups between graves. In several of them, both during the Early NeolithicMiddle Neolithic and the Late Neolithic-Early Bronze Age, haplogroups indicate that people from the same maternal lineage groups used the megalithic grave. In a few cases, individuals with similar haplogroups, $\mathrm{Sr}$ isotope ratios and radiocarbon dates appear in the same grave. In the Late Neolithic, significant differences in the $\mathrm{Sr}$ isotope ratios between individuals buried in gallery graves with and without port-holes occur. Furthermore, significant variations in the non-local $\mathrm{Sr}$ isotope ratios between gallery graves also occur. This might indicate differences in origin between the groups using the graves and/or different contact networks operating even for nearby graves. In some megalithic graves, there are indications of spatial patterning in the depositional practices of the dead. In the Middle Neolithic Valtorp 2 passage grave,
mtDNA haplogroups along with $\mathrm{Sr}$ isotope data and radiocarbon dates suggest that different family groups used specific parts of the grave chamber.

A few possible maternally related individuals in different contemporaneous graves were also observed, which could be a result of exogamous marriage patterns among different family groups. Nevertheless, shared mtDNA haplogroups do not necessarily imply close kinship but might reflect the population in more general terms. Kin relations between different megalithic graves have been suggested in other northern European Neolithic contexts based on aDNA analyses (Cassidy et al. 2020; Sánchez-Quintoa et al. 2019). To determine whether kinship groups actually used the graves, genome-wide aDNA analyses are required. An ongoing aDNA study, including nuclear aDNA data from some of the sampled individuals, is going to address this question as well as more general demographic aspects.

The megalithic burials may represent a segment of, or a certain hierarchical subgroup of society and/or certain families or groups. The high number of non-locals and semi-locals observed in the Falbygden graves could result from extended social groups with common social networks and traditions. Certain individuals or families from a larger geographical area (also from outside of Falbygden) might have been burying their dead in the megalithic graves of Falbygden for specific reasons. However, as contemporaneous settlements have been found in proximity to the Middle Neolithic megalithic graves (Sjögren 2003; Sjögren et al. 2019), it is unlikely that only people residing outside of Falbygden used the megalithic graves.

Our data suggest that individuals buried in the more peripheral parts of the graves mainly had Falbygden local ratios, while the main chambers in the megalithic graves were used to bury both individuals with local and non-local ratios. The non-locals might represent a population fragment with high mobility and/or first-generation immigrants, while the individuals with local ratios possibly were less mobile or at least moved in a geographically more limited area or during shorter times. Thus, the megalithic population primarily intended for the grave might have been more mobile than other or later populations and considered more important and therefore placed in a central part of the grave. However, more samples from different parts of the graves would be required to investigate this further.

Individuals with local as well as non-local $\mathrm{Sr}$ isotope ratios were reusing older megalithic graves in Late Neolithic-Early Bronze Age. Of these specific burials, the early Late Neolithic individuals displayed non-local $\mathrm{Sr}$ isotope ratios, while most of the Late Neolithic II depositions in passage graves exhibited local ratios. A plausible scenario is that people moving into Falbygden in the first part of Late Neolithic buried some of their dead in older megalithic graves as a strategy of taking possession of the location or claiming a connection to former 
groups. In the Late Neolithic II, on the other hand, people/ families that moved in may have continued their own traditions of constructing gallery graves or used the megalithic graves they were familiar with, which also could explain the large variation of gallery graves in Late Neolithic II (Blank et al. 2020; Weiler 1994).

Our results concern individuals deposited in megalithic graves. Neolithic flat graves occur in the area, but they are limited to a few possible cases (Sahlström 1932; Sjögren 2003). The intensive farming and the few and limited archaeological excavations are some of the reasons for the scarcity. The spatial distribution of specific artefacts suggests that Neolithic flat graves probably occurred in larger numbers here, like in other regions of south Scandinavia (Blank in press; Kossian 2005; Lekberg 2002; Malmer 1962; Sjögren 2003). It is thus possible that the individuals buried in megalithic graves were more mobile than other groups, at least during some periods, but this cannot be determined before we find skeletal remains from other types of burials to compare with.

\section{Mobility patterns over time}

Previous Sr isotope studies suggested that $1 / 4$ of the people buried in Falbygden passage graves grew up in areas outside of Falbygden (Sjögren et al. 2009). The proportion of nonlocal cattle was even higher, with $\mathrm{Sr}$ isotope ratios indicating more varied and partly different areas of origin from those of humans (Sjögren and Price 2013a). According to our study, the proportion of Early Neolithic-Middle Neolithic humans exhibiting non-local ratios is slightly lower (18\%), which may result from a larger dataset and a slightly different division between the groups. According to Blank and Knipper (in press), about $60 \%$ of the Late Neolithic burials yielded non-local and semi-local isotope ratios, which more or less corresponds to the much larger dataset presented in this study. Furthermore, a couple of preliminary Sr isotope studies from gallery graves and dolmens (Blank et al. 2018b; Blank and Knipper in press) suggest that human mobility rates were higher and more varied during the Late Neolithic than in the previous period, which agrees with our results.

In Falbygden, at the end of the Early Neolithic (ca $3500 \mathrm{cal}$ BC) and throughout the first part of the Middle Neolithic people, mainly adults moved within Falbygden and in the surroundings of the sedimentary area. The mobility was probably linked to several different factors, such as animal husbandry and cultivation strategies, social and cultural networks with neighbouring megalithic settlements and other settlements further away. The networks extending outside of Falbygden might have been upheld by the exchange of cattle but also by social networks of other kinds (compare Sjögren and Price 2013a).
An adult female dated to the Middle Neolithic A exhibited relatively low ${ }^{87} \mathrm{Sr} /{ }^{86} \mathrm{Sr}$ and might originate from Scania or other regions with similar $\mathrm{Sr}$ isotope ranges. In a previous study (Sjögren et al. 2017), a young female dated to the Early Neolithic found in a bog in Falbygden has been suggested to have moved in from Scania based on $\mathrm{Sr}$ isotope analysis.

Unfortunately, only three individuals were dated to the Middle Neolithic B, and two of them exhibited $\mathrm{Sr}$ isotope ratios indicating migrations from more southern regions such as Scania or Denmark. Then, there is a gap of at least 400 years when the megalithic graves were not used for burials, and no other skeletal remains are available. This period is represented by the BAC and overlaps with the abovementioned burials. In Falbygden, the presence of the BAC is mainly recognized by finds of battle axes, flint axes and pottery. Thus, we cannot say anything about the mobility in Falbygden during this time, but according to aDNA studies previously mentioned, these people originated from $\mathrm{CW}$ groups that moved to southern Scandinavia from continental Europe.

In the Late Neolithic, people became more mobile, especially from the transition between Late Neolithic I and II, and people seem to have moved in groups to a greater extent including females, males and children. Humans moved over larger areas than in the previous period, and individuals from new locations to the east/northeast migrated into Falbygden. In the second part of the Late Neolithic, clusters of females and males with similar $\mathrm{Sr}$ isotope ratios were observed. The growing mobility in the Late Neolithic was mainly connected to movements between Falbygden and locations outside of the sedimentary area. Growing long-distance exchange networks and migrations of families establishing in Falbygden, where climate changes (see below) and population pressure might have been possible triggers, could explain these movements. The exchange networks, from ca 2000 cal BC, may partly have been maintained by marriage alliances.

Studies based on ${ }^{18} \mathrm{O}$ isotopes in lake sediments and pollen data from western Sweden suggest a temperature decline around $2000 \mathrm{cal} \mathrm{BC}$, at the transition between Late Neolithic I and II (Hammarlund et al. 2003: 267; Seppä et al. 2005). According to Hammarlund et al. (2003: 267), at this time, a dramatic shift over a few hundred years took place towards a more humid, cooler and less stable climate. This event most probably had implications for how people moved in the landscape (as indicated by the $\mathrm{Sr}$ isotope data) due to possible changes of subsistence strategies and land use. Other factors affecting the mobility patterns and social organization at this time might have been growing long-distance exchange networks and demographic changes.

Considering the amber and flint artefacts recovered in the megalithic graves, contacts with the coastal areas, Scania and Denmark, can be assumed (Anderbjörk 1932; Axelsson et al. 
2015; Apel 2001; Sjögren 2003). However, the Sr isotope data from the Middle Neolithic A and the Late Neolithic-Early Bronze Age do not indicate permanent mobility between Falbygden and these areas (with the exception of data from one Middle Neolithic A and two Middle Neolithic B individuals). Thus, the artefacts might reflect indirect exchange networks consisting of several nodes within a larger distribution system. Nevertheless, direct contacts may also be possible as short-term movements may be difficult to trace using $\mathrm{Sr}$ isotope analysis. Similarities between the pottery found in the graves and pottery from south Scandinavian and north European contexts can be observed during both periods, indicating shared traditions over larger areas (Bagge and Kaelas 1950-52; Iversen 2015; Müller and Peterson 2015; Sjögren 2003; Stilborg 2002; Strömberg 1971). More exotic artefacts, such as the amber pendant in Luttra 16 and the bronze and gold spirals in Torbjörntorp 18 (Supplementary Material 2), may indicate expanded exchange networks in the Late Neolithic. The higher variation of $\mathrm{Sr}$ isotope ratios and mtDNA haplogroups in the Late Neolithic/Early Bronze Age skeletal remains could be a result of generally increased population pressure and human migrations taking place in the Nordic region. Both these hypotheses are in accordance with the general assumptions about the Scandinavian Late Neolithic (see above).

\section{Concluding remarks}

According to our results, there is a significant increase of human mobility and a greater variation of mobility patterns among the Late Neolithic megalithic population of Falbygden compared to the Early Neolithic-Middle Neolithic phase. Similar developments in other regions of Sweden indicate that this is a general trend.

In Falbygden, ratios suggesting a possible origin from the west coast or Scania only occur in a few individuals during the latter part of Middle Neolithic, while ratios found east and northeast of Falbygden only appear in the Late Neolithic. Thus, partly changed mobility patterns and contact networks can be assumed. Furthermore, the greater variation of $\mathrm{Sr}$ isotope ratios and mtDNA haplogroups as well as evidence of movements both in and out of Falbygden suggest more people moving into Falbygden from further away, but also a generally increased mobility of the megalithic population in the landscape over larger regions in the Late Neolithic-Early Bronze Age than in the Early Neolithic-Middle Neolithic.

We observed changes in mobility patterns between Early Neolithic-Middle Neolithic and Late Neolithic-Early Bronze Age and during the Late Neolithic-Early Bronze Age considering age of death and biological sex. During the Early Neolithic-Middle Neolithic, among the individuals displaying non-local ratios, only adults and young adults could be confirmed, indicating that adults migrated into Falbygden or were brought here to be buried. During the Late Neolithic-Early Bronze Age, the non-locals mainly represented children and adults, suggesting that both these categories migrated into Falbygden, potentially partly consisting of family groups. In Late Neolithic II-Early Bronze Age, the difference in Sr isotope ratios between sexes was significant, unlike in earlier periods where this correlation was not present.

Our data indicate that different maternal lineage groups used specific compartments in passage graves during the Early Neolithic-Middle Neolithic and specific gallery graves in the Late Neolithic-Early Bronze Age. We suggest that the megalithic graves in Falbygden were mainly used by kin groups, although supplementary investigation is needed.

In Falbygden, the greater variation of ${ }^{87} \mathrm{Sr} /{ }^{86} \mathrm{Sr}$ isotope ratios, mtDNA haplogroups, $\delta^{15} \mathrm{~N}$ and the greater variation of megalithic grave constructions in the Late Neolithic-Early Bronze Age, compared to the Early Neolithic-Middle Neolithic, point to a more heterogeneous society that could be described as a melting pot of different groups from various locations.

A peak of non-local $\mathrm{Sr}$ ratios and of variability in $\mathrm{Sr}$ isotope ratios and mtDNA haplogroups occur in the Late Neolithic II. At the same time, cooling temperatures and increasing precipitation occur in western Sweden. Thus, we propose a distinct change in mobility at the onset of Late Neolithic II potentially connected to a climate change, a shift in economic and social structures and an expansion of exchange networks and to a generally increased population.

Supplementary Information The online version contains supplementary material available at https://doi.org/10.1007/s12520-021-01294-4.

Acknowledgements We are grateful for help with sampling and osteology to Anna Tornberg, Lund University, Maria Vretemark, Västergötlands museum, Leena Drenzel and Johnny Karlsson, Statens historiska museum, and Clara Alfsdotter and Astrid Lennblad, Bohusläns museum. Sandra Kraus, Melanie Lorenz, Gerlinde Borngässer, Sigrid Klaus and Bernd Höppner (CEZA gGmbH Mannheim) contributed to $\mathrm{Sr}$ isotope sample preparation and analysis. Sequencing was performed at the SNP\&SEQ Technology Platform, National Genomics Infrastructure (NGI), and computations were conducted using Uppsala Multidisciplinary Center for Advanced Computational Science (UPPMAX), both in Uppsala, Sweden. For comments and suggestions, we thank T. Douglas Price and anonymous reviewers.

Authors' contributions Conceptualization, visualization, material preparation, data collection and data analysis were performed by Malou Blank. Sampling was done by Jan Storå and Malou Blank and osteological analyses conducted by Jan Storå. Funding acquisition was done by Mattias Jakobsson, Anders Götherström and Jan Storå. Corina Knipper supervised the strontium isotopic analyses. Helena Malmström, Magdalena Fraser and Emma Svensson, supervised and performed the 
laboratory analyses and the genetic analyses. Mattias Jakobsson, Helena Malmström, Magdalena Fraser and Torsten Günther supervised and performed population genetic analyses. Hannes Yngve performed genetic analyses. Malou Blank wrote the article with input from Karl-Göran Sjögren, Corina Knipper, Jan Storå, Karin M Frei, Helena Malmström and Magdalena Fraser. Karl-Göran Sjögren contributed with supervision and revisions. All authors read and approved the final manuscript.

Funding Open access funding provided by University of Gothenburg. This work was supported by The Swedish Research Council, VR 20131905 and Riksbankens Jubileumsfond, grant no. M13-0904:1 and Knut and Alice Wallenberg foundation within the project Atlas of Ancient Human Genomes in Sweden.

\section{Declarations}

Conflict of interest The authors declare that they have no conflict of interest.

Open Access This article is licensed under a Creative Commons Attribution 4.0 International License, which permits use, sharing, adaptation, distribution and reproduction in any medium or format, as long as you give appropriate credit to the original author(s) and the source, provide a link to the Creative Commons licence, and indicate if changes were made. The images or other third party material in this article are included in the article's Creative Commons licence, unless indicated otherwise in a credit line to the material. If material is not included in the article's Creative Commons licence and your intended use is not permitted by statutory regulation or exceeds the permitted use, you will need to obtain permission directly from the copyright holder. To view a copy of this licence, visit http://creativecommons.org/licenses/by/4.0/.

\section{References}

Åberg G (1995) The use of natural strontium isotopes as tracers in environmental studies. Water Air Soil Pollut 79:309-322

Åberg G, Wickman FE (1987) Variations of the ${ }^{87} \mathrm{Sr} /{ }^{86} \mathrm{Sr}$ in water from streams discharging into the Bothnian Bay, Baltic Sea. Nord Hydrol $18: 33-42$

Ahlström T (2009) Underjordiska dödsriken - humanosteologiska studier av neolitiska kollektivgravar. University of Gothenburg, Gothenburg

Allentoft ME, Sikora M, Sjögren K-G, Rasmussen S, Rasmussen M, Stenderup J et al (2015) Population genomics of Bronze Age Eurasia. Nature 522:167-172. https://doi.org/10.1038/nature14507

Anderbjörk JE (1932) Västergötlands megalitgravar. Västergötlands Fornminnesförenings tidskrift IV:5-6: 5-38

Andersson J, Söderlund U, Cornell D, Johansson L, Möller C (1999) Sveconorwegian (- Grenvillian) deformation, metamorphism and leucosome formation in SW Sweden, SW Baltic Shield: constraints from a Mesoproterozoic granite intrusion. Precambrian Res 98:151171

Apel J (2001) Daggers, knowledge \& power. Dissertation, Uppsala University

Arcini C, Price TD, Cinthio M, Drenzel L, Andersson M, Persson B, Menander H, Vretemark M, Kjellström A, Hedvall R, Tagesson G (2016) Living conditions in times of plague. In: Lagerlås P (ed) Environment, Society and the Black Death: An interdisciplinary approach to the late-medieval crisis in Sweden. Oxbow books, Oxford chap. 6
Artursson M (2009) Bebyggelse och samhällsstruktur. Södra och mellersta Skandinavien under senneolitikum och bronsålder 2300$500 \mathrm{f}$. Kr. Dissertation, Gothenburg University

Axelsson T (2010) Landskap - Visuella \& rumsliga relationer i Falbygdens neolitikum. Dissertation, Gothenburg University

Axelsson T, Ramstad M, Strinnholm A (2015) Amber. In: Fowler C, Harding J, Hofmann D (eds) The oxford handbook of Neolithic Europe. Oxford University Press, Oxford, pp 651-571

Bagge A and Kaelas L (1950-52) Die Funde aus Dolmen und Ganggräbern in Schonen, Schweden 1-2. Kungliga VitterhetsHistorie. Och Antikvitetsakademien, Stockholm

Bentley RA (2006) Strontium isotopes from the earth to the archaeological skeleton: A review. J Archaeol Method Theory 13:135-187

Bergerbrant S, Kristiansen K, Allentoft ME, Frei KM, Price TD, Sjögren $\mathrm{K}-\mathrm{G}$ et al (2017) Identifying commoners in the Early Bronze Age: burials outside barrows. In: Bergerbrant $\mathrm{S}$, Wessman A (eds) New Perspectives on the Bronze Age: Proceedings from the 13th Nordic Bronze Age Symposium, held in Gothenburg 9th June 2015. Archaeopress, Oxford, pp 37-64

Berglund BE (2003) Human impact and climate changes-synchronous events and a causal link? Quat Int 105:7-12

Blank M (2016) Prehistoric activities in megalithic graves in Falbygden, Sweden. Lund Archaeol Rev 21:49-70

Blank M (2017) Bronze Age burials in megalithic graves in Falbygden. In: Bergerbrant S, Wessman A (eds.) New Perspectives on the Bronze Age: Proceedings from the 13th Nordic Bronze Age Symposium, held in Gothenburg 9th June 2015. Archaeopress, Oxford, pp 19-36

Blank M (2019) Tracing dietary change of the megalithic population in Southwestern Sweden. In: Müller J, Hinz M, Wunderlich M (eds.) Megaliths- societies- landsacapes. Early monumentality and social differentiations in Northern Europe, Vol. 3. Proceedings of the international the conference "Megaliths, Societies, Landscape, Early Monumentality and Social Differentiation in Neolithic Europe", $16^{\text {th }}-20^{\text {th }}$ juni 2015 in Kiel. Verlag Dr. Rudolf Habelt GmbH, Bonn, pp 691-704

Blank M, Knipper C (in press) Neolithic mobility in western Sweden: interpretations of strontium isotope ratios of the megalithic population in Falbygden. In: Gibson C, Frieman C, Cleary K (eds) Making Journeys. Archaeologies of Mobility. Oxbow books, Oxford

Blank M, Sjögren K-G, Knipper C, Frei KM, Storå J (2018a) Isotope values of the bioavailable strontium in inland southwestern Sweden-A baseline for mobility studies. PLoS ONE 13(10): e0204649. https://doi.org/10.1371/journal.pone.0204649

Blank M, Sjögren K-G, Storå J (2020) Old bones or early graves? Megalithic burial sequences in southern Sweden based on 14C datings. Archaeol Anthropol Sci 12. https://doi.org/10.1007/s12520020-01039-9

Blank M, Tornberg A, Knipper C (2018b) New perspectives on the Late Neolithic of south western Sweden. An interdisciplinary investigation of the gallery grave Falköping stad 5. Open Archaeol 4:1-35

Bramanti B (2013) The use of DNA analysis in the archaeology of death and burial. In: Tarlow S, Nilsson Stutz L (eds) The Oxford Handbook of The Archaeology of Death and Burial. Oxford University Press, Oxford, pp 99-122

Brusgaard' NØ, Fokken H, Kootker LM (2019) An isotopic perspective on the socio-economic significance of livestock in Bronze Age West-Frisia, the Netherlands (2000-800 BCE). J Archaeol Sci : Reports 27. https://doi.org/10.1016/j.jasrep.2019.101944

Cassidy LM, Maoldúin RO, Kador T, Lynch A, Jones C, Woodman PC, Murphy E, Ramsey G, Dowd M, Noonan A, Campbell C, Jones ER, Mattiangeli V, Bradley DG (2020) A dynastic elite in monumental Neolithic society. Nature 582:384-388. https://doi.org/10.1038/ s41586-020-2378-6

Ebbesen K (1996) Die nordischen Bernsteinhorte der Tricherbecherkultur. Prähistorische Zeitschrift, 1995/1: 32-89 
Ebbesen K (2007) Danske hellekister fra stenalderen. Aarbøger for nordisk Oldkyndighed og Historie 2004:7-62

Edenmo R (2008) Prestigeekonomi under yngre stenåldern: gåvoutbyten och regionala identiteter i den svenska båtyxekulturen, Occasional papers in archaeology OPIA 43. Department of Archaeology and Classical studies, University of Uppsala, Uppsala

Egfjord AF-H, Margaryan A, Fischer A, Sjögren K-G, Price TD, Johannsen NN, Nielsen PO, Sørensen L, Willerslev E, Iversen R, Sikora M, Kristiansen K, Allentoft ME, Biehl PF (2021) Genomic steppe ancestry in skeletons from the Neolithic single grave culture in Denmark. PLoS One 16(1):e0244872

Enevold R (2019) Åsle Mosse (FHM 4296/2669). A quantitative study of a Holocene vegetation record - pollen analysis of a 6.5-meter peat core from Åsle Mosse, south-central Sweden and an estimation of vegetation land cover changes during almost 10.000 years using REVEALS modelling. Report no. 49, Afdelning for Konservering og Naturvidenskab, Moesgaard Museum, Aarhus

Ericson JE (1985) Strontium isotope characterization in the study of prehistoric human ecology. J Hum Evol 14:503-514

Eriksson G, Frei KM, Howcroft R, Gummesson S, Molin F, Lidén K, Frei R, Hallgren F (2016) Diet and mobility among Mesolithic huntergatherers in Motala (Sweden) - The isotope perspective. J Archaeol Sci Rep 17:904-918. https://doi.org/10.1016/j.jasrep.2016.05.052

Eriksson G, Linderholm A, Fornander E, Kanstrup M, Schoultz P, Olofsson H, Lidén K (2008) Same island, different diet: Cultural evolution of food practice on Öland, Sweden, from the Mesolithic to the Roman Period. J Anthropol Archaeol 27:520-543

Evans JA, Montgomery J, Wildman G, Boulton N (2010) Spatial variations in biosphere $87 \mathrm{Sr} / 86 \mathrm{Sr}$ in Britain. J Geol Soc Lond 167:754 764

Faure G (1986) Principles of isotope geology, 2nd edn. Wiley, New York

Fibiger L, Ahlström T, Bennike P, Schulting RJ (2013) Patterns of violence-related skull trauma in neolithic southern scandinavia. Am J Phys Anthropol 150(2):190-202

Fornander E, Lidén K, Eriksson G, Andersson P (2015) Identifying mobility in populations with mixed marine/terrestrial diets: Strontium isotope analysis of skeletal material from a passage grave in Resmo, Öland, Sweden. In: Suchowska-Ducke P, Reiter SS, Vandkilde H (eds) Forging Identities. The Mobility of Cultures in Bronze Age Europe: Vol. 1. BAR International Series S2771. Archaeopress, Oxford, pp 183-191

Fotakis AK, Rakownikow R, Christensen J, Blank M, Tornberg A, Mackie M, Götherström A, Storå J, Olsen JV, Sjögren K-G, Cappellini E (In preparation) Unravelling the dairying habits of Neolithic Swedes using shotgun proteomics

Fraser M (2018) People of the Dolmens and Stone cists. An archaeogenetic investigation of megalithic graves from the Neolithic period on Gotland. Dissertation, Uppsala University

Fraser M, Sanchez-Quinto F, Evans J, Storå J, Götherström A, Wallin P, Knutsson K, Jakobsson M (2018a) New insights on cultural dualism and population structure in the Middle Neolithic Funnel Beaker culture on the island of Gotland. J Archaeol Sci Rep 17:325-334

Fraser M, Sjödin P, Sanchez-Quinto F, Evans J, Svedjemo G, Knutsson K, Götherström A, Jakobsson M, Wallin P, Storå J (2018b) The Stone Cist Conundrum. A multidisciplinary approach to investigate Late Neolithic/Early Bronze Age population demography on the Island of Gotland. J Archeol Sci Rep 20:324-337

Frei KM, Bergerbrant S, Sjögren K-G, Jørkov ML, Lynnerup N, Harvig L, Allentoft ME, Sikora M, Price TD, Frei R, Kristiansen K (2019a) Mapping human mobility during the third and second millennia BC in present-day Denmark. PLoS ONE 14(8):e0219850. https://doi. org/10.1371/journal.pone.0219850

Frei KM, Frei R (2011) The geographic distribution of strontium isotopes in Danish surface waters - A base for provenance studies in archaeology, hydrology and agriculture. Appl Geochem 26:326-340
Frei KM, Frei R (2013) The geographic distribution of $\mathrm{Sr}$ isotopes from surface waters and soil extracts over the island of Bornholm (Denmark) - A base for provenance studies in archaeology and agriculture. Appl Geochem 38:147-160

Frei KM, Mannering U, Kristiansen K, Allentoft ME, Wilson AS, Skals I et al (2015) Tracing the dynamic life story of a Bronze Age Female. Sci Rep 5:10431

Frei KM, Price TD (2012) Strontium isotopes and human mobility in prehistoric Denmark. J Anthropol Archaeol Sci 4:103-114

Frei R, Frei KM, Jessen S (2019b) Shallow retardation of the strontium isotope signal of agricultural liming - implications for isoscapes used in provenance studies. Sci Total Environ. https://doi.org/10.1016/j. scitotenv.2019.135710

Gerling C, Doppler T, Heyd V, Knipper C, Kuhn T, Lehmann MF et al (2017) High-resolution isotopic evidence of specialised cattle herding in the European Neolithic. PLoS ONE 12(7):e0180164. https://doi.org/10.1371/journal.pone.0180164

Glykou A, Eriksson G, Storå J, Schmitt M, Kooijman E, Lidén K (2018) Intra- and inter-tooth variation in strontium isotope ratios from prehistoric seals by laser ablation (LA)-MC-ICP-MS. Rapid Commun Mass Spectrom. https://doi.org/10.1002/rcm.8158

Goodman AH, Armelagos GJ, Rose JC (1980) Enamel hypoplasias as indicators of stress in three prehistoric populations from Illinois. Hum Biol:515-528

Gron KJ, Montgomery J, Nielsen PO, Nowell GM, Peterkin JL, Sørensen $\mathrm{L}$ et al (2016) Strontium isotope evidence of early Funnel Beaker Culture movement of cattle. J Archaeol Sci Rep 6:248-251

Gron KJ, Montgomery J, Rowley-Conwy P (2015) Cattle management for dairying in Scandinavia's earliest Neolithic. PLoS ONE 10(7): e0131267. https://doi.org/10.1371/journal.pone.0131267

Günther T, Malmström H, Svensson EM, Omrak A, Sánchez-Quinto F, Kilınç GM et al (2018) Population genomics of Mesolithic Scandinavia: Investigating early postglacial migration routes and high-latitude adaptation. PLoS Biol 16(1):e2003703. https://doi. org/10.1371/journal.pbio.2003703

Haak W, Lazaridis I, Patterson P, Rohland N, Mallick S, Llamas B et al (2015) Massive migration from the steppe was a source for IndoEuropean languages in Europe. Nature 522:207-211. https://doi. org/10.1038/nature 14317

Hammarlund D, Björck S, Buchardt B, Israelson C, Thomsen CT (2003) Rapid hydrological changes during the Holocene revealed by stable isotope records of lacustrine carbonates from Lake Igelsjön, southern Sweden. Q Sci Rev 22:353-370

Hedenstierna-Jonson C, Kjellström A, Zachrisson T, Krzewińska M, Sobrado V, Price N, Günther T, Jakobsson M, Götherström A (2017) A female Viking warrior confirmed by genomics. Am J Phys Anthropol 164(4):853-860. https://doi.org/10.1002/ajpa. 23308

Hillson S (1996) Dental anthropology. Cambridge University Press, Cambridge

Hinders J (2011) Dödsrikets livshistorier. Benkemiska isotopanalyser på artikulerade och disartikulerade individer I Frälsegårdens gånggrift (Master thesis Univ. Stockholm 2011)

Hollund H, Blank M, Sjögren K-G (2018) Dead and buried? Variation in post-mortem histories revealed through histotaphonomic characterisation of human bone from megalithic graves in Sweden. PLoS ONE 13(10):e0204662. https://doi.org/10.1371/journal.pone. 0204662

Iversen R (2015) The Transformation of Neolithic Societies. An Eastern Danish Perspective on the 3rd Millenium BC. Aarhus University press, Aarhus

Janson S (1938) Västsvenska och västeuropeiska stenkammargravar med gavelhål. Fornvännen 33:321-342

Juras A, Chyleński M, Ehle E et al (2018) Mitochondrial genomes reveal an east to west cline of steppe ancestry in Corded Ware populations. Sci Rep 8:11603. https://doi.org/10.1038/s41598-018-29914-5 
Kaelas L (1967) Megalithic tombs in South Scandinavia - migration or cultural influence? Paleohistoria 12:287-322

Kaldhussæter Lindboe K (2014) Arkeologi på molekylnivå: Lipidanalyser av 8 keramikkskår fra Logården, thesis in Laborativ Arkeologi Stockholm University, Stockholm

Klassen L, Price TD, Sjögren K-G, Wincentz L, Philippsen B (2020) Strontium and lead isotope studies of faunal and human remains from Kainsbakke and Kirial Bro. In: Klassen L (ed.) The Pitted Ware Culture on Djursland. Uncovering the supra-regional importance and contacts of a South-Scandinavian landscape in the Middle Neolithic. East Jutland Museum Publications vol. 5. Aarhus University Press, Aarhus

Knipper C (2011) Die räumliche Organisation der linearbandkeramischen Rinderhaltung Naturwissenschaftliche und archäologische Untersuchungen. BAR International Series 2305. Archaeopress, Oxford

Knipper C, Mittnik A, Massy K, Kociumaka C, Kucukkalipci I, Maus M, Wittenborn F, Metz S, Staskiewicz A, Krause J, Stockhammer PW (2017) Female exogamy and gene pool diversification at the transition from the Final Neolithic to the Early Bronze Age in central Europe. Proc Natl Acad Sci 114:10083-10088. https://doi.org/10. 1073/pnas. 1706355114

Kossian R (2005) Nichtmegalitische Grabanlagen der Trichterbecherkultur in Deutschland und den Niederlanden. Veröffentlichungen des Landesamtes für Denkmalpflege und Archäologie Sachsen-Anhalt, Halle. Halle (Saale): Landesmuseum für Vorgeschichte

Kristiansen K, Larsson TB (2005) The rise of Bronze Age society: travels, transmissions and transformations. Cambridge University Press, Cambridge

Larsson ÅM (2009) Breaking and making bodies and pots: material and ritual practices in Sweden in the third millenium BC. Dissertation, Uppsala University

Larsson SÅ, Tullborg E-L (2015) Sveriges berggrund, en geologisk skapelseberättelse. Risbergs Information \& Media, Udevalla

Lekberg P (2002) Yxors liv, människors landskap: en studie av kulturlandskap och samhälle i Mellansveriges senneolitikum. Dissertation, Uppsala University

Lennblad A (2015) Döden i hällkistan. En material och litteraturstudie kring senneolitikums hällkistegravar. Unpublished master thesis, University of Gothenburg

Lewis J, Coath CD, Pike A (2014) An improved protocol for $87 \mathrm{Sr} / 86 \mathrm{Sr}$ by laser ablation multi-collector inductively coupled plasma mass spectrometry using oxide reduction and a customised plasma interface. Chem Geol 390:173-181

Lidén K (1995) Megaliths, agriculture and social complexity: A diet study of two Swedish Megalith populations. J Anthropol Archaeol $14: 404-417$

Linderholm A (2008) Migration in prehistory : DNA and stable isotope analyses of Swedish skeletal material. Dissertation, Stockholm University

Linderholm A, Fornader E, Eriksson G, Mörth C-M, Lidén K (2014) Increasing Mobility at the Neolithic/Bronze Age Transition - sulphur isotope evidence from Öland, Sweden. 'Human Exploitation of Aquatic Landscapes' special issue. In: Fernandes R, Meadows J (eds) Internet Archaeology, vol 37. https://doi.org/10.11141/ia.37. 10

Lindström M, Lundqvist J, Lundqvist T (2000) Sveriges geologi från urtid till nutid. Studentlitteratur, Lund

Ling J, Stos-Gale Z, Hjärtner-Holdar E, Grandin L, Billström K, Persson P (2014) Moving metals II: provenancing Scandinavian Bronze Age artefacts by lead isotope and elemental analyses. J Archaeol Sci 41: $106-132$

Loberg B (1999) Geologi. Material, processer och Sveriges berggrund, 6th edn. Prisma, Stockholm
Löfvendahl R, Åberg G, Hamilton PJ (1990) Strontium in rivers of the Baltic Basin. Aquat Sci 52(4):316-333

Malmer MP (1962) Jungneolitische Studien. Acta Archaeologica Lundensia, series 8o, Vol. 2. CWK Gleerups Förlag, Lund

Malmer MP (2002) The Neolithic of south Sweden: TRB, GRK, and STR. Royal Swedish Academy of Letters, History, and Antiquities : Distributed by Almquist \& Wiksell International, Stockholm

Malmström H, Gilbert M, Thomas M, Brandström M, Storå J et al (2009) Ancient DNA Reveals Lack of Continuity between Neolithic Hunter-Gatherers and Contemporary Scandinavians. Curr Biol 19(20):1758-1762

Malmström H, Linderholm A, Liden K, Storå J, Molnar P et al (2010) High frequency of lactose intolerance in a prehistoric huntergatherer population in northern Europe. BMC Evol Biol 10:89

Malmström H, Linderholm A, Skoglund P, Storå J, Sjödin P, Gilbert MTP, Holmlund G, Willerslev E, Jakobsson M, Lidén K, Götherström A (2015) Ancient mitochondrial DNA from the northern fringe of the Neolithic farming expansion in Europe sheds light on the dispersion process. Philos Trans R Soc B Biol Sci 370: 20130373-20130373. https://doi.org/10.1098/rstb.2013.0373

Malmström H, Günter T, Svensson EM, Juras A, Fraser M, Munters AR, Prospieszny L, Tõrv M, Lindström J, Götherström A, Storå J (2019) The genomic ancestry of the Scandinavian Battle Axe Culture people and their relation to the broader Corded Ware horizon. Proc $\mathrm{R}$ Soc B 286:20191528. https://doi.org/10.1098/rspb.2019.1528

Mittnik A, Wang C-C, Pfrengle S, Daubaras M, Zarina G, Hallgren F, Allmäe R, Khartanovich V, Moiseyev V, Tõrv M et al (2018) The genetic prehistory of the Baltic Sea region. Nat Commun 9:442

Montelius O (1905) Orienten och Europa. Antiqvarisk Tidskrift för Sverige XIII:1-252

Montgomery J (2010) Passports from the past. Investigating human dispersals using strontium isotope analysis of tooth enamel. Ann Hum Biol 37:325-346. https://doi.org/10.3109/03014461003649297

Montgomery J, Evans JA (2006) Immigrants on the Isle of Lewis - combining traditional funerary and modern isotope evidence to investigate social differentiation, migration and dietary change in the Outer Hebrides of Scotland. In: Gowland R, Knusel C (eds) The Social Archaeology of Funerary Remains. Oxbow Books, Oxford, Oxford, pp 122-142

Müller J, Peterson R (2015) Ceramics and Society in Northern Europe. In: Fowler C, Harding J, Hofmann D (eds) The Oxford handbook of Neolithic Europe. Oxford University press, Oxford, pp 572-605

Nelson SJ, Ash M (2010) Wheeler's Dental Anatomy, Physiology, and Occlusion, 9th edn. Saunders Elsevier, Missouri

Oelze VM, Nehlich O, Richards MP (2012) There is no place like home'-No isotopic evidence for mobility at the Early Bronze Age Cemetery of Singen, Germany. Archaeometry 54(4):752-778

Olalde I, Brace S, Allentoft M et al (2018) The beaker phenomenon and the genomic transformation of northwest Europe. Nature 555:190 196. https://doi.org/10.1038/nature25738

Påsse T, Pile O (2016) Beskrivningar till jordartskartorna 8D Skara NV, NO, SV och SO och 9D Mariestad SV. K 534-538. Sveriges geologiska undersökningar, Uppsala

Persson P, Sjögren K-G (1995) Radiocarbon and the chronology of Scandinavian megalithic graves. J Eur Archaeol 3:59-88

Persson P, Sjögren KG (2001) Falbygdens gånggrifter. Undersökningar 1985-1998. GOTARC Serie C no. 34. Gothenburg University, Gothenburg

Prescott C (2005) Settlement and economy in the Late Neolithic and Bronze Age of Southern Norway: Some Points and Premises. AmS-Varia 43:127-136

Price TD, Burton JH, Bentley RA (2002) The Characterization of Biologically Available Strontium Isotope Ratios for the Study of Prehistoric Migration. Archaeometry 44(1):117-135 
Price TD, Knipper C, Grupe G, Smrcka V (2004) Strontium isotopes and prehistoric human migration: The Bell Beaker Period in Central Europe. Eur J Archaeol 7(1):9-40

Price TD, Naumann E (2015) The peopling of the North Atlantic: Isotopic results from Norway. J North Atlant Special Volume 7:88-102

Rascovan N, Sjögren K-G, Kristiansen K, Nielsen R, Willerslev E et al (2019) Emergence and Spread of Basal Lineages of Yersinia pestis during the Neolithic Decline. Cell 176(1):295-305

Retzius G (1899) Crania Suecica Antiqua: beskrifning av svenska mennisko-kranier från stenåldern, bronsåldern och järnåldern jämte en blick på forskningen öfver de europeiska folkens ras-karaktärer. Stockholm

Sahlström KE (1932) Gudhems härads fornminnen. Skövdeortens Hembygds- och Fornminnesförenings skriftserie nr. 3. Skövdeortens Hembygds- och Fornminnesförenings Redaktionsutskott, Skövde

Sánchez-Quintoa F, Malmströma H, Fraser M, Girdland-Flin L, Svensson EM, Simões LG, George R, Hollfelder N, Burenhult G, Noble G, Britton K, Talamo S, Curtis N, Brzobohat H, Sumberov R, Götherström A, Storå J, Jakobsson M (2019) Megalithic tombs in western and northern Neolithic Europe were linked to a kindred society. Proc Natl Acad Sci U S A 116(19):9469-9474

Schnell J-B (1966) Vatten och fornfynd. Bebyggelsehistoriska studier på Västergötlands kambrosilurområde (Dissertation, Gothenburg 1966)

Schulz Paulsson B (2010) Scandinavian models: radiocarbon dates and the origin and spreading of passage graves in Sweden and Denmark. Radiocarbon 52(2-3): 1002-1017

Schulz Paulsson B (2017) Time and stone: the emergence and development of megaliths and megalithic societies in Europe. Archaeopress Archaeology, Oxford

Sealy JC, Armstrong R, Schrine C (1995) Beyond lifetime averages: tracing life histories through isotopic analysis of different calcified tissues from archaeological human skeletons. Antiquity 69:290-300

Seppä H, Hammerlund D, Antonsson K (2005) Low-frequency and highfrequency changes in temperature and effective humidity during the Holocene in south-central Sweden: implications for atmospheric and oceanic forcings of climate. Clim Dyn 25:285-297

Schroeder H, Margaryan A, Szmyt M, Theulot B, Wlodarczak P, Rasmussen $\mathrm{S}$ et al (2019) Unraveling ancestry, kinship, and violence in a Late Neolithic mass grave. PNAS 116(22):10705-10710. https://doi.org/10.1073/pnas.1820210116

Simonsen J (2017) Daily Life at the Turn of the Neolithic. A comparative study of longhouses with sunken floors at Resengaard and nine other settlements in the Limfjord region, South Scandinavia. Aarhus universitetsforlag, Aarhus

Sjögren K-G (2003) "Mångfalldige uhrminnes grafvar ..." Megalitgravar och samhälle i Västsverige. Dissertation, Gothenburg University

Sjögren K-G (2011) C-14 chronology of Scandinavian megalithic tombs. Menga:103-120

Sjögren K-G (2015a) News from Frälsegården. Aspects of Neolithic burial practices. In: Brink K, Hydén S, Jennbert K, Larsson L, Olausson D (eds.) Neolithic Diversities Perspectives from a conference in Lund, Sweden. Acta Archaeologica Lundensia, Series in 80. 65. Lund, Sweden. Lund University, Lund, pp 200-10

Sjögren K-G (2015b) Mortuary practices, bodies and persons in Northern Europe. In: Fowler C, Harding J, Hofmann D (eds) The Oxford Handbook of Neolithic Europe. Oxford University Press, Oxford, pp 1005-1022

Sjögren K-G (2017) Modeling middle Neolithic funnel beaker diet on Falbygden, Sweden. J Archaeol Sci Rep 12:295-306

Sjögren K-G, Ahlström T, Blank M, Price TD, Frei KM, Hollund HI (2017) Early Neolithic human bog finds from Falbygden, western Sweden. New isotopic, osteological and histological investigations. J Neolithic Archaeol 19:97-124
Sjögren K-G, Axelsson T, Vretemark M (2019) Middle Neolithic economy in Falbygden, Sweden. Preliminary results from Karleby Logården. In: Müller J., Hinz M, Wunderlich M (eds.) MegalithsSocieties- Landsacapes. Early monumentality and social differentiations in Northern Europe, Vol. 3. Proceedings of the international the conference "Megaliths, Societies, Landscape, Early Monumentality and Social Differentiation in Neolithic Europe", $16^{\text {th }}-20^{\text {th }}$ juni 2015 in Kiel. Verlag Dr. Rudolf Habelt GmbH, Bonn, pp 705-718

Sjögren K-G, Price TD (2013a) A complex Neolithic economy: isotope evidence for the circulation of cattle and sheep in the TRB of western Sweden. J Archaeol Sci 40:690-704

Sjögren K-G, Price TD (2013b) Vegetarians or meat eaters? Enamel $\delta 13 \mathrm{C}$ and Neolithic diet at the Frälsegården passage tomb, central Sweden. In: Bergerbrant S, Sabatini S (eds) Counterpoint: Essays in Archaeology and Heritage Studies in Honour of Professor Kristian Kristiansen. Archaeopress, Oxford, pp 690-704

Sjögren K-G, Price TD, Ahlström T (2009) Megaliths and Mobility in South-western Sweden. Investigating Relations between a Local Society and its Neighbours Using Strontium Isotopes. J Anthropol Archaeol 28:85-101

Sjögren K-G, Olalde I, Carver S, Allentoft ME, Knowles T, Kroonen G, Pike AWG, Schröter P, Brown KA, Brown KR, Harrison RJ, Bertemes F, Reich D, Kristiansen K, Heyd V, Halcrow SE (2020) Kinship and social organization in copper age Europe. A cross-disciplinary analysis of archaeology, DNA, isotopes, and anthropology from two bell beaker cemeteries. PLoS One 15(11):e0241278

Skoglund P, Malmström H, Omrak A, Raghavan M, Valdiosera C, Gunther $\mathrm{T}$ et al (2014) Genomic diversity and admixture differs for Stone-Age Scandinavian foragers and farmers. Science 344(6185):747-750. https://doi.org/10.1126/science.1253448

Skoglund P, Malmström H, Raghavan M, Storå J, Hall P, Willerslev E et al (2012) Origins and Genetic Legacy of Neolithic Farmers and Hunter-Gatherers in Europe. Science 336(6080):466-469. https:// doi.org/10.1126/science.1216304

Snoeck C, Jones C, Pouncett J, Goderis S, Claeys P, Mattielli N, Zazzo A, Reimer PJ, Lee-Thorp JA, Schulting RJ (2020) Isotopic evidence for changing mobility and landscape use patterns between the Neolithic and Early Bronze Age in western Ireland. JAS: Reports 30:102214

Stilborg O (2002) Neolitikum. In: Lindahl A, Olausson D, Carlie A (eds) Keramik I Sydsverige, en handbook föe arkeologer, Insitute of archaeology: report series no. 81. University of Lund, Malmö, pp 57 80

Strömberg M (1968) Der Dolmen Trollasten in St Köpinge, Schonen. Acta Archaeologica Lundesia Series In 8 No. 7. Rudolf Habelt Verlag GmbH/CWK Gleerups Förlag, Bonn/Lund

Strömberg M (1971) Die Megalithgräber von Hagestad. Zur Problematik von Grabbauten und Grabriten. CWK Gleeups, Lund/Bonn

Thomsen E, Andreasen R (2019) Agricultural lime disturbs natural strontium isotope variations: Implications for provenance and migration studies. Sci Adv 5(3):eaav8083

Tornberg A (2017) Diet toothache and burial diversity. Tracing social status through bioarchaeological methods in Late Neolithic-Early Bronze Age Scania. Lund Archaeol Rev 22:21-36

Tornberg A (2018) Health, cattle and ploughs: Bioarchaeological consequences of the Secondary Products Revolution in southern Sweden, 2300-1100 BCE. Dissertation, Lund University

Vandkilde H (1996) From Stone to Bronze. The Metalwork of the Late Neolithic and Earliest Bronze Age in Denmark. Dissertation, Aarhus University

Vandkilde H (2016) Bronzization: the Bronze Ageas pre-modern globalization. Praehistorische Zeitschrift 91:103-223

Watts P, Howe P (2010) Strontium and strontium compounds. Concise International Chemical Assessment Document, vol 77. World Health Organization (WHO), Geneva, pp 1-67 
Weiler E (1994) Innovationsmiljöer i bronsålderns samhälle och idévärld: kring ny teknologi och begravningsritual i Västergötland. Dissertation, Umeå Universitet

Wilhelmson H, Ahlström T (2015) Iron Age migration on the island of Öland: Apportionment of strontium by means of Bayesian mixing analysis. J Archaeol Sci 64:30-45
Wilhelmson H, Price TD (2017) Migration and integration on the Baltic island of Öland in the Iron Age. J Archaeol Sci Rep 1:183-196

Publisher's Note Springer Nature remains neutral with regard to jurisdictional claims in published maps and institutional affiliations. 